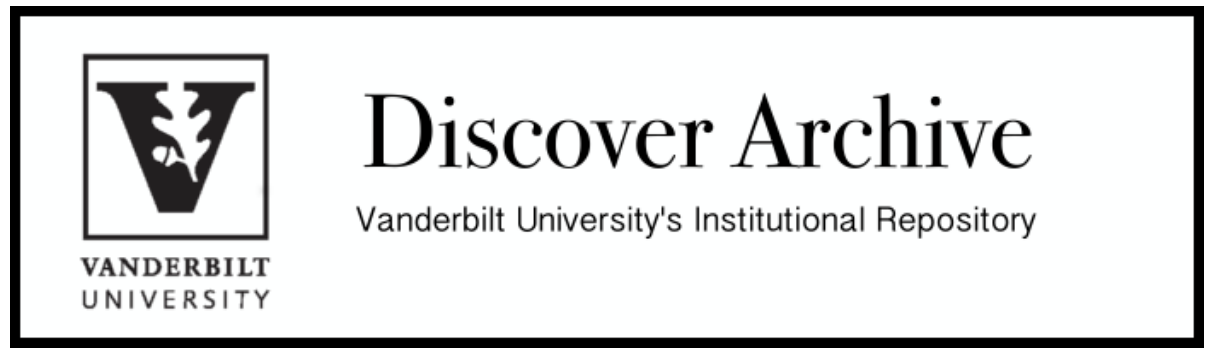

This work was originally published as: James F. Cotter, Alan R. Palmiter, and Randall S. Thomas, The First Year of Say-On Pay Under Dodd-Frank: An Empirical Analysis and Look Forward - 81 George Washington Law Review 967 (2013). 


\section{HEINONLINE}

Citation: 81 Geo. Wash. L. Rev. 9672013

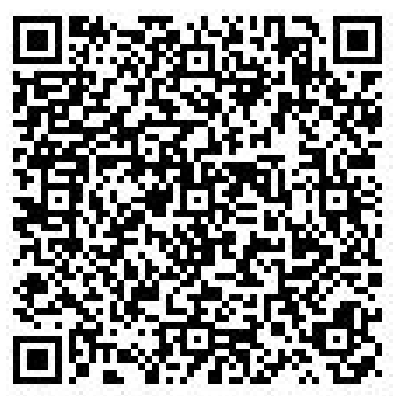

Content downloaded/printed from

HeinOnline (http://heinonline.org)

Tue Apr 22 11:01:56 2014

-- Your use of this HeinOnline PDF indicates your acceptance of HeinOnline's Terms and Conditions of the license agreement available at http://heinonline.org/HOL/License

-- The search text of this PDF is generated from uncorrected OCR text.

-- To obtain permission to use this article beyond the scope of your HeinOnline license, please use:

https://www.copyright.com/ccc/basicSearch.do?

\&operation $=$ go\&search $\mathrm{Type}=0$

\&lastSearch $=$ simple\&all=on\&titleOrStdNo=0016-8076 


\title{
The First Year of Say-on-Pay Under Dodd-Frank: An Empirical Analysis and Look Forward
}

\author{
James F. Cotter* \\ Alan R. Palmiter** \\ Randall S. Thomas***
}

\begin{abstract}
Using voting data from the first year of say-on-pay votes under DoddFrank, we look at the patterns of shareholder voting in advisory votes on executive pay. Consistent with the more limited say-on-pay voting before DoddFrank, we find that shareholders in the first year under Dodd-Frank generally gave broad support to management pay packages. But not all pay packages received strong shareholder support. At some companies, management suffered the embarrassment of failed say-on-pay votes-that is, less than fifty percent of their company's shareholders voted in favor of the proposal. In particular, we find that poorly performing companies with high levels of "excess" executive pay, low total shareholder return, and negative Institutional Shareholder Services ("ISS") voting recommendations experienced greater shareholder "against" votes than at other firms.

Although say-on-pay votes are non-binding and corporate boards need not take action even if the proposal fails, most companies receiving negative ISS recommendations or experiencing low levels of say-on-pay support undertook additional communication with shareholders or made changes to their pay practices, reflecting a shift in the management-shareholder dynamic. During 2012, the second year of say-on-pay under Dodd-Frank, we find similar patterns, with companies responding proactively to an unfavorable ISS recommendation or a prior failed (or even weak) say-on-pay vote in 2011 . We use four case studies to illustrate this new corporate governance dynamic, which we view as an important consequence of the Dodd-Frank Act.
\end{abstract}

\section{TABLE OF Contents}

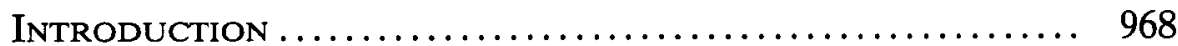

I. Say-on-Pay in the United States ............... 971

A. The Say-on-Pay Debate ..................... 971

1. Arguments for Say-on-Pay............... 971

2. Arguments Against Say-on-Pay ............ 974

* Thomas S. Goho Chair of Finance and Associate Professor of Finance at Wake Forest University School of Business.

** Howard L. Oleck Professor of Business Law, School of Law, Wake Forest University.

*** John S. Beasley II Chair in Law and Business, Vanderbilt Law School, Professor of Management, Owen School of Business, Vanderbilt University.

April 2013 Vol. 81 No. 3 
B. Dodd-Frank's Say-on-Pay Mandate and SEC Implementation ........................... 977

II. Shareholder Say-on-Pay Voting in $2011 \ldots \ldots \ldots . . .979$

A. Effect of ISS Recommendations on Say-on-Pay Votes....................................... 981

B. Effect of Other Factors on Say-on-Pay Voting ..... 984

1. Effect of "Total Stock Return" .............. 984

2. Effect of CEO Pay Growth................ 987

3. Effect of "Excess" CEO Pay ................ 988

C. Multivariate Analysis: Sorting out Factors ......... 990

III. SAy-on-PAy in 2012 Proxy Season ................ 992

A. Getting Ready for Say-On-Pay in 2012: Aftermath of 2011 ................................... 993

1. Company Responses to Say-on-Pay in 2011 ... 993

2. Company (and Shareholder) Responses to Negative ISS Recommendations in 2011 ...... 995

3. Shareholder Litigation Following Failed 2011

Say-on-Pay Votes .......................... 997

B. Say-on-Pay in 2012: Early Results.............. 998

C. Company Responses to Negative ISS

Recommendations: Four Case Studies ............ 1002

1. Case 1: Shuffle Master..................... 1002

2. Case 2: Disney .......................... 1004

3. Case 3: Adobe Systems .................. 1006

4. Case 4: Huntington Bancshares .............. 1008

Conclusions ............................................ 1010

\section{INTRODUCTION}

Executive pay in U.S. public companies is controversial. ${ }^{1} \mathrm{Re}-$ formers say it is excessive and set by captured boards, ${ }^{2}$ while supporters say it reflects a well-functioning market. ${ }^{3}$ Some legal academics say it creates perverse and even dangerous incentives, ${ }^{4}$ while some fi-

1 See Randall S. Thomas, Alan R. Palmiter \& James F. Cotter, Dodd-Frank's Say on Pay: Will it Lead to a Greater Role for Shareholders in Corporate Governance?, 97 CoRnEll L. REv. 1213,1215 (2012).

2 See, e.g., Lucian Bebchuk \& Jesse Fried, Pay Without Performance: The Unfulfilled Promise of Executive Compensation 80-86, 121-36 (2004).

3 See, e.g., John E. Core, Wayne R. Guay \& Randall S. Thomas, Is U.S. CEO Compensation Inefficient Pay Without Performance?, 103 Mich. L. Rev. 1142 (2005) (reviewing BEBCHUK \& FRIED, supra note 2).

4 See, e.g., Jennifer Hill \& Charles M. Yablon, Corporate Governance and Executive Remuneration: Rediscovering Managerial Positional Conflict, 25 U. NEw S. WALEs L.J. 294 (2002). 
nance scholars say, if structured properly, it rewards the right things. ${ }^{5}$ Now, with the Dodd-Frank Wall Street Reform and Consumer Protection Act of 2010 ("Dodd-Frank"), ${ }^{6}$ shareholders also have a say. Dodd-Frank gives shareholders in larger U.S. public companies the right to an advisory vote on the prior year's pay of their companies' top five executives-a say-on-pay. ${ }^{7}$

In this Article, we ask whether Dodd-Frank has made a difference in how shareholders vote on executive pay practices and whether Dodd-Frank has changed the dynamic in shareholder-management relations in U.S. companies. Using voting data from the first year of say-on-pay votes under Dodd-Frank, we look at the patterns of shareholder voting in advisory votes on executive pay. As we anticipated, based on the more limited experience with say-on-pay voting before Dodd-Frank, ${ }^{8}$ shareholders in the first year under Dodd-Frank generally gave broad support to management pay packages.

Yet, during the first year under Dodd-Frank, not all pay packages received strong shareholder support. At some companies, management suffered the embarrassment of failed say-on-pay votes-that is, less than fifty percent of their company's shareholders voted in favor of the proposal. In particular, we find that poorly performing companies with high levels of "excess" executive pay, low total shareholder return, and negative voting recommendations from the third party voting advisor Institutional Shareholder Services (ISS) experienced greater shareholder "against" votes than at other firms. ISS and other third party voting advisors appeared to have played a significant role in mobilizing shareholder opposition-and often a management response-at these firms.

Although say-on-pay votes are non-binding and corporate boards need not take action even if the proposed pay package fails to garner majority support, most companies receiving negative ISS recommendations or experiencing low levels of say-on-pay support undertook additional communication with shareholders or made changes to their pay practices, reflecting a change in their interactions with sharehold-

5 See, e.g., Michael C. Jensen \& Kevin J. Murphy, Remuneration: Where We've Been, How We Got to Here, What Are the Problems, and How to Fix Them (Harvard Bus. Sch., NOM Research Paper No. 04-28, ECGI Fin. Working Paper No. 44/2004, 2004), available at http:// papers.ssrn.com/sol3/papers.cfm?abstract_id=561305.

6 Dodd-Frank Wall Street Reform and Consumer Protection Act ("Dodd-Frank"), Pub. L. No. 111-203, 124 Stat. 1375 (2010).

7 See id. $\$ 951,124$ Stat. at 1899-900; see also 17 C.F.R. $\$ 229.402$ (2012) (requiring disclosure of compensation of the top five executives).

8 See Thomas, Palmiter \& Cotter, supra note 1, at 1216. 
ers. During 2012, the second year of say-on-pay under Dodd-Frank, we find similar patterns, with companies responding proactively when the company comes onto shareholders' radar screens because of an unfavorable ISS recommendation or an earlier poor, or failed, say-onpay vote in 2011. We use four case studies to illustrate this new dynamic.

In all, our findings suggest that the Dodd-Frank say-on-pay mandate has not broadly unleashed shareholder opposition to executive pay at U.S. companies, as some proponents had hoped for. Nonetheless, it has affected pay practices at outlier companies experiencing weak performance and high executive pay levels that are identified by proxy advisory firms like ISS. In addition, mandatory say-on-pay seems to have encouraged management to be more responsive to shareholder concerns about executive pay and corporate governance. ${ }^{9}$ This shift in management-shareholder relations may be the most important consequence of Dodd-Frank thus far.

This Article proceeds as follows: Part I describes the Dodd-Frank say-on-pay legislation and the SEC's implementation of the DoddFrank Act, as well as the academic debate over say-on-pay. Part II contains our empirical analysis of the 2011 say-on-pay voting results, looking at both univariate and multivariate results that demonstrate the importance of ISS voting recommendations along with several other firm-specific variables, including total shareholder return, "excess" pay levels, and CEO pay growth rates. Part III examines the aftermath of say-on-pay during the 2011 proxy season and the preliminary 2012 say-on-pay voting results, which show more negative ISS voting recommendations and more companies with failed votes than at the same point in the 2011 proxy voting season. We find management at these and other companies exhibiting a more proactive attitude toward say-on-pay votes and undertaking greater engagement with shareholders. We offer four case studies as examples of the strategies that companies have adopted in response to negative ISS voting recommendations. Finally, we conclude with several observations about how the Dodd-Frank say-on-pay mandate has and may continue to shape U.S. corporate governance.

9 See id., at 1256-57 (discussing examples of management responding to shareholder concerns by making "changes to the substance and disclosure of their pay programs"). 


\section{Say-on-Pay in the United States}

The idea of say-on-pay began in the United Kingdom in 2002 and spread to the United States in 2006 as a fledgling movement by activist shareholders. ${ }^{10}$ The financial crisis of 2008 bolstered these activists, as Congress sought to address perceived problems in our corporate governance system, including executive pay. ${ }^{11}$ Dodd-Frank included among its many changes a mandate that all public companies give their shareholders an advisory vote on the company's actual pay practices. ${ }^{12}$ Before and since Dodd-Frank, academics have debated the merits of say-on-pay. In this Section, we describe this academic debate and the predictions about say-on-pay before its enactment; we then lay out the background of the Dodd-Frank say-on-pay regime.

\section{A. The Say-on-Pay Debate}

Even before Dodd-Frank imposed its say-on-pay mandate, academics actively debated the merits of federally requiring a shareholder vote on executive pay. ${ }^{13}$ This say-on-pay debate rehashed the question of whether mandatory corporate law, particularly at the federal level, should displace enabling state law. Those arguing for a sayon-pay mandate viewed a uniform federal standard across all public companies to be preferable to a voluntary company-by-company approach that had already begun with shareholder proposals under Rule $14 a-8 .{ }^{14}$

\section{Arguments for Say-on-Pay}

Proponents of mandatory say-on-pay pointed to the U.K., which in 2002 "became the first country to adopt requirements for shareholder votes on [executive] pay." 15 The legislation required U.K. incorporated companies "listed on major U.K. or foreign stock exchanges" to submit "an executive remuneration report" annually to shareholders and to "submit such report to a nonbinding shareholder vote at the annual meeting." 16 The U.K. say-on-pay mandate sought

10 For a history of say-on-pay in the United Kingdom and the United States, see id., at 1217-24, 1226-28.

11 See id. at 1218.

12 See id.

13 See id. at 1226.

1417 C.F.R. $\S 240.14 a-8$ (2012) (governing when shareholder proposals must be included in a proxy statement).

15 Stephen Deane, Say on Pay: Results from Overseas, CoRP. BoARd, July-Aug. 2007, at $11,12$.

16 See Sudhakar Balachandran, Fabrizio Ferri \& David Maber, Solving the Executive 
to address "concerns among the public and institutional investors regarding excessive executive pay."17

Soon after, in 2004, Australia and the Netherlands also adopted say-on-pay reforms. ${ }^{18}$ The Dutch law calls for "a binding, rather than a merely an [sic] advisory" one, but the vote does not necessarily happen annually and "the shareholders vote on compensation policies, not on a retrospective report."19 Then, "Sweden in 2006 and Norway in 2007 both enacted legislation similar to the Dutch model, requiring a binding shareholder vote on compensation policies."20

Academic studies looking at the U.K. experience with say-on-pay have generally painted a favorable picture, though with results less dramatic than some expected. Sudhakar Balachandran, Fabrizio Ferri, and David Maber compared U.K. pay practices before and after the U.K. say-on-pay mandate, and concluded that the new rule had increased pay-for-performance sensitivity at U.K. companies. ${ }^{21}$ Another study by Ferri and Maber, looking at the impact of the U.K. legislation on stock prices for companies with high executive pay and the voting results under the U.K. say-on-pay regime, found that shareholders reacted favorably to the legislation and later to specific pay reforms at companies receiving negative votes on their pay practices. ${ }^{22}$ Professors Ferri and Maber concluded:

We document a positive market reaction to the announcement of say on pay regulation for firms with controversial CEO pay practices and, more specifically, weak penalties for poor performance, consistent with shareholders perceiving say on pay as a value enhancing monitoring mechanism. We also find that firms respond to high voting dissent by removing controversial provisions criticized as rewards for failure,

Compensation Problem Through Shareholder Votes? Evidence from the U.K. 4-5 (Nov. 2007) (unpublished manuscript), available at http:/www7.gsb.columbia.edu/ciber/sites/default/files/ balchandranCIBER_Grant_Paper_UK_Voting.pdf.

17 Id. at 5; see also Memorandum from Michael J. Segal, Senior Partner, Wachtell, Lipton, Rosen \& Katz, U.K. Gov't Announces Binding Vote on Exec. Comp. (June 21, 2012) (on file with author) (describing the U.K.'s recent adoption of proposals that "give shareholders a binding vote on the executive pay policy of listed companies" in that country).

18 See Regan Adamson \& Daniel Lumm, Shareholder Democracy and the Say on Pay Movement: Progress, But How Do You Define Success? 3 (unpublished manuscript) (on file with the Wake Forest Law Review), available at http:/wakeforestlawreview.com/wp-content/uploads/ 2012/09/Adamson_Lumm_SOP_Draft-1.pdf.

19 Id.

20 Id.

21 Balachandran, Ferri \& Maber, supra note 16 , at 1.

22 Fabrizio Ferri \& David Maber, Say on Pay Votes and CEO Compensation: Evidence from the UK, 17 Rev. FiN. 527, 559 (2013). 
such as long notice periods and retesting provisions for option grants. Finally, we find a significant increase in the sensitivity of CEO pay to poor performance, particularly among firms that experience [high dissent] at the first vote and firms with excess CEO pay before the regulation. ${ }^{23}$

Besides pointing to the U.K. experience, academic proponents of mandatory say-on-pay for U.S. companies argued that more transparency and accountability would lead to greater efficiency and social responsiveness. ${ }^{24}$ They also argued that say-on-pay would help boards negotiate pay packages with CEOs more effectively on behalf of shareholders. ${ }^{25}$ Further, the say-on-pay proponents assumed that shareholders would be able to identify companies with poorly designed pay packages and vote against them. ${ }^{26}$

Proponents of say-on-pay also asserted that the ISS and the other proxy advisory firms would help inform shareholders, particularly institutional shareholders, so that they could coordinate their monitoring of management and thus reduce managerial agency costs. ${ }^{27}$ They argued that ISS and other proxy voting advisors created and periodically revised their voting guidelines on say-on-pay, and that this would foster institutional shareholder activism and help institutional clients fulfill their fiduciary duties to exercise portfolio share votes effectively. ${ }^{28}$ This coordinating function, it was argued, saved institutional shareholders the costs of separately doing their own voting research, resulting in the underproduction of voting information and valuable

23 Id.

24 See, e.g., Empowering Shareholders on Executive Compensation: Hearing on H.R. 1257 Before the H. Comm. on Fin. Servs., 110th Cong. 65-68 (2007) [hereinafter House Hearings] (written testimony of Lucian Bebchuk, William J. Friedman and Alicia Townsend Friedman Professor of Law, Economics, and Finance and Director of the Corporate Governance Program, Harvard Law School).

25 Id. at 68; Stephen Davis, Does "Say on Pay" Work? Lessons on Making CEO Compensation Accountable, in Fifth Annual Directors' Institute on Corporate Governance 33, 46 (PLI Corporate Law \& Practice, Course Handbook Ser. No. B-1622, 2007).

26 House Hearings, supra note 24, at 65-66 (written testimony of Lucian Bebchuk, William J. Friedman and Alicia Townsend Friedman Professor of Law, Economics, and Finance and Director of the Corporate Governance Program Harvard Law School) (concluding that say-on-pay votes "will annually provide companies with valuable information about how their shareholders view company performance in this critical test").

27 This coordination function is illustrated by the say-on-pay voting during the 2011 proxy season, when all of the companies that failed to receive majority support for their say-on-pay resolutions also had received an "against" recommendation by the ISS. See infra Part II.

28 See Paul Rose, The Corporate Governance Industry, 32 J. CoRP. L. 887, 899-903 (2007) (describing business and operations of ISS, as well as duties of private pension plans under the Employee Retirement Income Security Act ("ERISA") to vote portfolio shares so as to protect plan assets). 
monitoring. ${ }^{29}$ Proponents argued that the ISS would monitor company pay practices and formulate voting advice to shareholders, both to paying clients and others who use the publicly available ISS voting recommendations..$^{30}$ In addition, proponents of say-on-pay anticipated that the ISS would serve as representative for shareholder voting interests, with company management negotiating directly with the ISS to obtain a favorable voting recommendation or to reverse an unfavorable one. ${ }^{31}$

Some proponents further predicted that a mandatory shareholder say-on-pay vote would dampen the spiral in executive pay ${ }^{32}$ and "deter some egregious compensation arrangements." 33 Others anticipated that a say-on-pay vote would strengthen the relationship between pay and performance, thus reducing payment for failure ${ }^{34}$ For example, in written testimony before Congress, Professor Lucian Bebchuk urged that shareholders receive an advisory vote on executive pay at U.S. companies, concluding that such a vote would allow shareholders to express their views when pay was not connected to company performance. ${ }^{35}$

\section{Arguments Against Say-on-Pay}

Skeptics of say-on-pay asserted that a federally mandated shareholder vote on executive pay (whether advisory or binding) would upset the balance of authority between the corporate board and

29 See Robert Charles Clark, Corporate Law 389-94 (1986) (classic description of shareholder voting in public corporations, which presents collective action problems similar to the "prisoner's dilemma").

30 Stephen J. Choi \& Jill E. Fisch, How To Fix Wall Street: A Voucher Financing Proposal for Securities Intermediaries, 113 YALE L.J. 269, 294-95 (2003) (describing role and influence of ISS, which operates on a limited budget).

31 See Robin Sidel et al., ISS Is Put in the Spotlight as H-P Claims Victory, WaLl ST. J., Mar. 20, 2002, at C20 (stating that ISS's recommendation for the Hewlett-Packard and Compaq merger "helped bolster H-P's position in one of the most contentious proxy battles in recent years").

32 The evidence, however, seems to be to the contrary thus far. See Nathaniel Popper, C.E.O. Pay, Rising Despite the Din, N.Y. TIMEs, June 17, 2012, at BU1 (noting that data from 2011 revealed that the "median pay raise" of "the nation's 200 top-paid C.E.O.'s [sic]" was five percent from the prior year).

33 See Lucian A. Bebchuk \& Holger Spamann, Regulating Bankers' Pay, 98 Geo. L.J. 247, 276 (2010) (commenting on the possible effects of say-on-pay for Troubled Asset Relief Program ("TARP") recipients).

34 E.g., House Hearings, supra note 22, at 65-66 (written testimony of Lucian Bebchuk, William J. Friedman and Alicia Townsend Friedman Professor of Law, Economics, and Finance and Director of the Corporate Governance Program Harvard Law School).

35 Id. 
shareholders. ${ }^{36}$ For example, Timothy J. Bartl, Senior Vice President and General Counsel of The Center on Executive Compensation, argued that "[s]ay on pay would undermine the authority of the Board of Directors under the U.S. system of corporate governance." ${ }^{37}$ A mandatory say-on-pay vote would be superfluous because, under the existing allocation of shareholder and board powers, shareholders could already express their concerns about executive pay-through direct dialogue with management, the casting of "no" or "withhold" votes against directors sitting on underperforming compensation committees, or the approval of shareholder resolutions seeking individual company say-on-pay votes. ${ }^{38}$

Academic opponents asserted that a mandatory say-on-pay vote would create few benefits, as shareholders could already use Rule 14a8 to propose such a vote, and a mandatory vote was certain to produce additional costs..$^{39}$ Some critics questioned whether shareholders would be able to identify differences in pay plans, potentially leading to uninformed say-on-pay votes. ${ }^{40}$ Other critics predicted that some shareholders would use say-on-pay to advance their political agendas. ${ }^{41}$ Professor Jeffrey Gordon doubted that U.S. shareholders would be interested in say-on-pay, pointing to the U.K experience where shareholders had overwhelmingly approved pay packages put to a vote, with only eight negative votes in the first six years of U.K. sayon-pay. ${ }^{42}$ Moreover, Gordon pointed out that overall shareholder

36 See Thomas, Palmiter \& Cotter, supra note 1 , at 1228.

37 See Letter from Timothy J. Bartl, Senior Vice President \& Gen. Counsel, Ctr. on Exec. Comp., to Elizabeth M. Murphy, Sec'y, U.S. Sec. \& Exch. Comm'n 2 (Sept. 8, 2009) [hereinafter Bartl Letter], available at http://www.sec.gov/comments/s7-12-09/s71209-46.pdf.

38 See id.

39 See House Hearings, supra note 24, at 126 (testimony of Steven N. Kaplan, Neubauer Family Professor of Entrepreneurship and Finance, University of Chicago School of Business); 17 C.F.R. \& 240.14a-8 (2012).

40 See, e.g., Bartl Letter, supra note 37, at 4-5.

41 See House Hearings, supra note 24, at 126 (testimony of Steven N. Kaplan, Neubauer Family Professor of Entrepreneurship and Finance, University of Chicago School of Business). The empirical evidence on this point, however, is mixed. Compare Jie Cai \& Ralph A. Walking, Shareholders' Say on Pay: Does It Create Value?, 46 J. Fin. \& Quantitative Analysis 299, 329 (2011) (finding that "when the say-on-pay proposals are spcnsored by labor unions, the market reacts significantly more negatively than otherwise"), with Yonca Ertimur, Fabrizio Ferri \& Volkan Muslu, Shareholder Activism and CEO Pay, 24 Rev. FIN. STUD. 535, 537 (2011) (finding that "union pension funds are not more likely to target unionized firms"). For a discussion of labor union shareholder activism, see generally Stewart J. Schwab \& Randall S. Thomas, $R e-$ aligning Corporate Governance: Shareholder Activism by Labor Unions, 96 MicH. L. REv. 1018 (1998).

42 Jeffrey N. Gordon, "Say on Pay": Cautionary Notes on the U.K. Experience and the Case for Shareholder Opt-In, 46 HARV. J. ON LEGIs. 323, 341 (2009) (explaining that "shareholders 
support in the United States for shareholder proposals seeking company-by-company say-on-pay votes had leveled off at about forty-two percent, suggesting that most shareholders were not taken by the concept. ${ }^{43} \mathrm{He}$ concluded that adopting say-on-pay to "better link pay and performance" in the United States would be a "dubious choice." 44

Other skeptics of say-on-pay argued that a mandatory regime would only increase the influence of proxy advisory firms, whose purportedly one-size-fits-all voting recommendations would be followed blindly by institutional shareholders. ${ }^{45}$ Some argued that management would thus become controlled by ISS-led shareholders, undermining management's discretionary authority. ${ }^{46}$ The critics also stated their concerns that ISS voting recommendations could be biased, since the firm both provides voting advice on pay packages and consults with companies on adopting pay policies. ${ }^{47}$

Some critics of say-on-pay questioned whether pay reform is necessary, asserting that pay and performance at public companies are linked. ${ }^{48}$ Testifying before Congress in 2007, Professor Steven Kaplan stated:

While there have clearly been abuses and unethical CEOs, pay for the typical CEO appears to be largely driven by market forces . . . . Firms with CEOs in the top decile of actual pay earned stock returns that were $90 \%$ greater than those of other firms in their industries over the previous 5 years. Firms with CEOs in the bottom decile of actual pay underperformed their industries by almost $40 \%$ in the previous

invariably approve the Directors Remuneration Report, with perhaps eight turndowns across thousands of votes over a six-year experience"); see also Thomas, Palmiter \& Cotter, supra note 1 , at $1230-31$.

43 Gordon, supra note 42, at 339 ("The number of [say-on-pay] proposals grew only moderately [in 2008], to seventy, and the level of shareholder support has remained at the same level, approximately forty-two percent.").

44 Id. at 325.

45 Stephen M. Bainbridge, The Corporate Governance Provisions of Dodd-Frank, ENGAGE, Dec. 2010, at 33, 33-34, available at http:/www.fed-soc.org/doclib/20101223_BainbridgeEngage11.3.pdf; see also Gordon, supra note 42, at 326, 350-52 (arguing that RiskMetrics, the "most important proxy advisor[,] . . . faces conflict issues in its dual role of both advising and rating firms on corporate governance [matters]" and predicting institutional shareholders would rely on proxy advisory firms, which would wield undue influence over say-on-pay votes).

46 Stephen N. Bainbridge, Dodd-Frank: Quack Federal Corporate Governance Round II, 95 Minn. L. Rev. 1779, 1815 (2011).

47 See Ctr. on Exec. Comp., A Call for Change in the Proxy Advisory Industry Status Quo 7-8 (2011), http://online.wsj.com/public/resources/documents/ProxyAdvisoryWhitePaper02072011.pdf; Gordon, supra note 42, at 326.

48 See Bainbridge, supra note 46, at 1809-10 (surveying literature and concluding that "[t]he core premise behind say-on-pay remains, at best, unproven"). 
5 years. The results are qualitatively similar if we look at performance over the previous three years or previous year. There can be absolutely no doubt that the typical CEO in the U.S. is paid for performance. ${ }^{49}$

Yet others doubted that say-on-pay would affect pay practices and corporate governance in the ways envisioned by its proponents. ${ }^{50}$ In a 2001 analysis of the say-on-pay concept, which was prescient in anticipating the reform movement for a shareholder role in executive pay, Professors Brian Cheffins and Randall Thomas concluded that say-on-pay would probably be used sparingly by U.S. shareholders to vote down pay packages that deviated "far from the norm." ${ }_{11}$ They predicted that say-on-pay votes would probably not stifle the upward spiral in executive pay. ${ }^{52}$

\section{B. Dodd-Frank's Say-on-Pay Mandate and SEC Implementation}

The Dodd-Frank Act mandates that shareholders in public companies be given a "yes" or "no" advisory vote on the pay of the company's top named executives during the prior fiscal year. ${ }^{53}$ DoddFrank also requires that such shareholders be given an advisory vote on the frequency of their say-on-pay vote and on any "golden parachute" payments made in any acquisition or merger. ${ }^{54}$ The votes, however, do not bind the directors or alter directors' duties to shareholders. ${ }^{55}$ Thus, Dodd-Frank specifies that any shareholder vote should not be construed to overrule any decision by the company or its board, or to imply any additional fiduciary duties for directors or officers. ${ }^{56}$

As added by Dodd-Frank, the new Section 14A of the Securities Exchange Act requires that management present "a separate resolution subject to shareholder vote to approve the compensation of executives," though the vote "shall not be binding on the issuer or the

49 House Hearings, supra note 24, at 122-23 (testimony of Steven N. Kaplan, Neubauer Family Professor of Entrepreneurship and Finance, University of Chicago School of Business) (describing study of CEO pay with Josh Rauh).

so See Thomas, Palmiter \& Cotter, supra note 1, at 1233.

51 Brian R. Cheffins \& Randall S. Thomas, Should Shareholders Have a Greater Say over Executive Pay?: Learning from the US Experience, 1 J. CORP. L. STUD. 277, 310, 315 (2001).

52 See id. at 315.

53 See Dodd-Frank Wall Street Reform and Consumer Protection Act, Pub. L. No. 111-203, § 951, 124 Stat. 1376, 1899 (codified at 15 U.S.C. $§ 78 n-1$ (Supp. IV 2011)).

54 See Dodd-Frank sec. 951, § 14A(a), (b), 124 Stat. at 1899 (codified at 15 U.S.C. § 78n$1(\mathrm{a}),(\mathrm{b}))$.

55 See id. sec. 951, §14A(c), 124 Stat. at 1900 (codified at 15 U.S.C. $\S 78 n-1$ (c)).

56 See id. 
board of directors." 57 Further, the inclusion by management of a sayon-pay proposal "may not be construed . . . to restrict or limit the ability of shareholders to make [their own] proposals for inclusion in the proxy materials related to executive compensation." 58

The SEC has implemented the Dodd-Frank say-on-pay mandate to specify the form of the say-on-pay proposal on which shareholders are to vote and the executive officers whose pay is subject to the shareholder vote. For public companies with more than a $\$ 75$ million public equity float, the SEC required say-on-pay votes at shareholder meetings held after January 20, 2011.59 The say-on-pay vote applies only to the company's CEO and the four other named executive officers included in the compensation table required in the Compensation Discussion \& Analysis ("CD\&A") section of the company's proxy statement. ${ }^{60}$ Shareholders are given a "for" or "against" vote on the company's overall executive pay package, but do not vote on the pay of specific officers or specific elements of pay (such as bonuses, stock options, retirement pay, and performance incentives). ${ }^{61}$

The SEC rules also required companies to disclose on Form 8-K the results of the say-on-pay vote within four business days of the

57 Id. sec. $951, \S 14 \mathrm{~A}(\mathrm{a})(1)$, (c), 124 Stat. at 1899-1900 (codified at 15 U.S.C. $\$ 78 \mathrm{n}-1$ (a)(1), (c)). In addition, affected companies must hold an advisory vote at least every six years on whether the say-on-pay vote will occur every one, two, or three years. Id. sec. 951, $\$ 14 \mathrm{~A}(\mathrm{a})(2)$, 124 Stat. at 1899 (codified at 15 U.S.C. $\$ 78 \mathrm{n}-1(\mathrm{a})(2)$ ).

58 Id. sec. $951, \S 14 \mathrm{~A}(\mathrm{c})(4), 124$ Stat. at 1900 (codified at 15 U.S.C. $\S 78 \mathrm{n}-1(\mathrm{c})(4)$ ).

59 See Shareholder Approval of Executive Compensation and Golden Parachute Compensation, 76 Fed. Reg. 6010, 6010, 6012 (Feb. 2, 2011). "Smaller reporting companies" become subject to the say-on-pay voting requirement for annual meetings after January 20, 2013. Id. at 6010 .

60 See 17 C.F.R. $\$ 240.14 a-21$ (a) (2012) (say-on-pay vote required at annual shareholder meetings at which directors are elected for named executives whose compensation is disclosed "pursuant to Item 402 of Regulation S-K"); id. \$ 229.402. "[T]he compensation of directors ... is not subject to the shareholder advisory vote." Shareholder Approval of Executive Compensation and Golden Parachute Compensation, 76 Fed. Reg. at 6014. The SEC rule does not require that the management-submitted say-on-pay proposal be phrased in a particular way, though it must indicate that the proposal seeks a "shareholder vote to approve the compensation of executives as disclosed pursuant to Item 402 of Regulation S-K." Id. at 6019. A suggested proposal calls on shareholders to approve " compensation paid . . . as disclosed pursuant to Item 402 of Regulation S-K, including the Compensation Discussion and Analysis, compensation tables and narrative discussion." Id. at 6014 n.68. "[A] vote to approve only compensation policies and procedures" would not pass muster. Id. at 6014 .

61 See 17 C.F.R. \$ 240.14a-21(a). In addition, the SEC added a comment to Rule $14 a-8$ that companies will be allowed to exclude shareholder-submitted proposals under the rule if the shareholder proposes a say-on-pay vote with "substantially the same scope as the say-on-pay vote required by Rule 14a-21(a)." Shareholder Approval of Executive Compensation and Golden Parachute Compensation, 76 Fed. Reg. at 6020. 
shareholders' meeting. ${ }^{62}$ In addition, the SEC required that companies disclose-in the next year's CD\&A-whether the board had considered the results of the shareholder say-on-pay vote as part of making its decisions about future pay levels and, if so, how the board did so. ${ }^{63}$ In its say-on-pay rulemaking, the SEC did not take a position on the say-on-pay debate. The agency neither expressed a view on the utility of say-on-pay nor whether say-on-pay would actually affect pay practices or levels. ${ }^{64}$

\section{Shareholder Say-on-Pay Voting in 2011}

In the 2011 proxy season, the inaugural year for the Dodd-Frank say-on-pay mandate, shareholders at over 2200 U.S. public companies voted on say-on-pay proposals submitted by management. ${ }^{65}$ Commentators reported that shareholders showed strong support for existing pay practices. On average, say-on-pay votes garnered $91.2 \%$ support, ${ }^{66}$ as over $70 \%$ of the companies conducting a say-on-pay vote garnered more than $90 \%$ support and over $90 \%$ of the companies garnered more than $70 \%$ support. ${ }^{67}$

Commentators identified forty-one Russell 3000 companies $^{68}$ at which shareholders voted down say-on-pay proposals, representing

62 See Sec. \& ExCh. CoMm'N, Form 8-K, at 18-19 (2013) (Item 5.07), available at http:// www.sec.gov/about/forms/form8-k.pdf; see also Shareholder Approval of Executive Compensation and Golden Parachute Compensation, 76 Fed. Reg. at 6016 n.100, 6020-21 (modifying what must be disclosed about shareholder votes on say-on-pay frequency, but not shareholder votes on say-on-pay resolution).

63 Shareholder Approval of Executive Compensation and Golden Parachute Compensation, 76 Fed. Reg. at 6043 (amending Item 402(b)(1) to require disclosure of how the company "considered the results of the most recent shareholder [say-on-pay] vote . . . in determining compensation policies and decisions and, if so, how that consideration has affected the registrant's executive compensation decisions and policies").

64 See generally id. at 6010.

65 Ted Allen et al., Institutional S'holder Servs. Inc., 2011 U.S. Postseason RePORT 7 (2011), http://www.issgovernance.com/files/private/2011_US_PostSeason_Report_ 0929.pdf. Equilar, a leading provider of data on executive pay, counted " 2,252 companies from the Russell 3000" as of June 30, 2011. See Equilar, Inc., An Analysis of Voting Results And Performance at Russell 3000 Companies 1 (2011), http:/www.equilar.com/knowledgenetwork/research-articles/2011/pdf/Equilar-Voting-Analytics-July2011.pdf.

66 ALLEN ET AL., supra note 65, at 1.

67 James D.C. Barrall, Alice M. Chung \& Julie D. Crisp, Proxy Season 2012: The Year of Pay for Performance, Director Notes, 1 (Apr. 2012), https:/www.conference-board.org/ retrievefile.cfm?filename=TCB-DN-V4N8-12.pdf \&type=subsite.

68 The Russell 3000 is an index "measur[ing] the performance of the largest 3000 U.S. companies representing approximately $98 \%$ of the investable U.S. equity market." Russell 3000 Index, Russell INVESTMENTs, https:/www.russell.com/Indexes/data/fact_sheets/us/Russell_3000 _Index.asp (last updated Feb. 28, 2013) 
"about 1.3 percent of the index," possibly based on shareholder concerns about pay for performance. ${ }^{69}$ Overall, negative say-on-pay votes in 2011 were correlated with company share returns and CEO pay. ${ }^{70}$

At all of the companies with failed say-on-pay votes in 2011, proxy advisory firms (particularly the ISS) had issued a negative voting recommendation..$^{71}$ But ISS voting recommendations did not always carry the day. There were far more negative ISS voting recommendations than failed say-on-pay votes. ${ }^{72}$ While the ISS recommended negative say-on-pay votes at 276 companies $(12.4 \%$ of the companies it reviewed), ${ }^{73}$ only 41 companies had a failed say-on-paythat is, about " 86 percent of the companies that received a negative recommendation from ISS," actually received majority support for their say-on-pay proposals. ${ }^{74}$

What factors drove say-on-pay voting in the 2011 proxy season? To answer this question-and to understand the disparity between ISS voting recommendations and actual voting results-we conducted an empirical analysis of the influence of several important factors that could explain the differences in shareholder voting patterns across various firms. We focused on the relationship between shareholder voting and total stock returns, total CEO pay, and the growth in CEO pay, because they were identified as important factors by the ISS in describing what seemed to influence shareholder say-on-pay voting. ${ }^{75}$

69 Stephen Joyce, Say-On-Pay Trend Negative, but Some Companies Rewarded for Making Changes, CORP. L. DAILY (BNA) (July 2, 2012), http://www.bna.com/corporate-law-daily-p6009/.

70 See id. (examining the correlation as a reason for differences in shareholder votes from 2011 to 2012).

71 Barrall, Chung \& Crisp, supra note 67, at 1.

72 Michael Littenberg, Farzad Damania \& Justin Neidig, A Closer Look at Negative Sayon-Pay Votes During the 2011 Proxy Season, Director Notes, 3-4 (Nov. 2011), https://www. conference-board.org/retrievefile.cfm?filename=TCB-DN-V3N14-111.pdf\&type=subsite.

73 See id. (noting that ISS "recommended a 'for' vote on [say-on-pay] at 1,949 companies" and a "negative recommendation" at 276 companies). The other major proxy advisory firm, Glass Lewis, made negative say-on-pay voting recommendations at a rate that was apparently similar to that of the ISS. See James D.C. Barrall \& Alice M. Chung, Say on Pay in the 2011 Proxy Season: Lessons Learned and Coming Attractions for U.S. Public Companies, Director Notes, 5 (July 2011), https://www.conference-board.org/retrievefile.cfm?filename=1293_ 1310462608.pdf \& type=subsite (noting that Glass Lewis is less transparent than the ISS in disclosing the firm's voting recommendations).

74 Littenberg, Damania \& Neidig, supra note 72, at 4.

75 The 2011 ISS proxy voting guidelines identified several key factors it considered in its recommendations on management say-on-pay proposals. INSTITUTIONAL S'HOLDERS SERvs. Inc., 2011 U.S. Proxy Voting Guidelines Summary 37 (2011) [hereinafter 2011 U.S. Proxy VOTING GUIDELINES SUMMARY], http://www.issgovernance.com/files/ISS2011USPolicySummary Guidelines20110127.pdf. These guidelines generally tracked the five "global principles" identified by the ISS in evaluating pay programs: (1) providing a "pay-for-performance alignment"; 
To conduct our Study, we acquired a commercial dataset compiled by ISS that included all voting results for the 2011 proxy season on say-on-pay proposals presented at Russell 3000 companies. ${ }^{76}$ For each of these companies, we then collected company data on total stock returns, total CEO pay, and growth in CEO pay. ${ }^{77}$ Although we received voting data for over 2600 companies, we only were able to obtain data on the relevant pay variables for 1497 firms, which we used as our final sample.

\section{A. Effect of ISS Recommendations on Say-on-Pay Votes}

Based on the results of our earlier research on say-on-pay voting before Dodd-Frank, ${ }^{78}$ we sought in this Study to quantify the effect of ISS voting recommendations on shareholder say-on-pay voting behavior after Dodd-Frank. The results of our research on say-on-pay voting before Dodd-Frank indicated that ISS voting recommendations had a significant (though not necessarily decisive) effect on shareholder say-on-pay voting, with an ISS voting recommendation resulting in an approximately twenty-five percent swing in how shareholders voted. ${ }^{79}$

Our pre-Dodd-Frank findings were consistent with those identified in a post-Dodd-Frank survey conducted by The Conference Board about how companies viewed ISS influence on say-on-pay votes. ${ }^{80}$ According to that survey, "[a] large majority of companies (70.4 percent) reported that their compensation programs were influ-

(2) "[a]void[ing] arrangements that risk 'pay for failure'"; (3) providing an "effective compensation committee"; (4) "[p]rovid[ing] shareholders with clear, comprehensive compensation disclosures;" and (5) "[a]void[ing] inappropriate pay" for outside directors. See id. The "ISS based negative SOP recommendations" in the 2011 proxy season largely on perceived disconnects between pay and performance, with specific attention to "year-over-year increases in executive compensation and the long-term trend of the CEO's total compensation relative to shareholder returns." Littenberg, Damania \& Neidig, supra note 72, at 4.

76 ISS analysts read company proxy statements to collect this information by hand.

77 We used both the Compustat and ExecuComp databases to compile this information. As discussed in connection with Table 5, see infra Part II.B.3 and infra note 96, we also collected data from these electronic databases to compute "excess pay," based on variable such as tenure of $\mathrm{CEO}$, company sales, company return on assets, company book value, company market value, company stock price, and S\&P 500 market price.

78 See Thomas, Palmiter \& Cotter, supra note1, at 1241-44.

79 See id. at 1255.

80 See David F. Larcker, Allan L. McCall \& Brian Tayan, The Influence of Proxy Advisory Firm Voting Recommendations on Say-on-Pay Votes and Executive Compensation Decisions, DIRECTOR NoTEs, 4 (Mar. 2012), https://www.conference-board.org/retrievefile.cfm? filename= TCB-DN-V4N5-12.pdf\&type=subsite. 
enced by the guidance received from proxy advisory firms or by the policies of these firms." 11 In particular, the survey showed:

Companies reported making a broad range of changes to their compensation program in response to proxy advisory firm policies. Roughly a third (31.7 percent) enhanced disclosure in the annual proxy, and 23.8 percent reduced or eliminated certain severance benefits. In addition, 15.8 percent reduced other benefits and perquisites, 12.9 percent adopted stock ownership guidelines or retention guidelines, and 8.9 percent introduced performance-based equity awards.

Approximately half of companies (51.2 percent) anticipate making changes to their executive compensation program for the 2012 proxy season. Companies are most likely to make changes to their disclosure policies and practices, to introduce performance-based equity awards, and to change to the peer group used for benchmarking purposes. . . .

The survey results clearly show that companies do respond to the [say-on-pay] policies adopted by proxy advisory firms. The majority of companies determine in advance whether their executive compensation programs are likely to receive a favorable recommendation from ISS or Glass Lewis; and companies are likely to make changes to a program in anticipation of a negative recommendation from these firms. All areas of the compensation program are affected, including disclosure, guidelines, and plan structure and design-although the degree to which these areas are affected varies considerably. ${ }^{82}$

For these reasons, we begin our empirical analysis of say-on-pay during the 2011 proxy season by looking at the relationship between ISS voting recommendations and actual shareholder voting.

As Table 1 below shows, of the 1497 ISS say-on-pay recommendations in our sample, the ISS issued an "against" recommendation 173 times ( $11.6 \%$ of the time). We can calculate a measure of how an ISS "against" recommendation impacts "for" votes by subtracting (1) the average percentage of "for" votes when the ISS gives a positive recommendation from (2) the average percentage of "against" votes when the ISS gives a negative recommendation. This difference is $28.2 \%$ - a crude measure of the "ISS effect." 83

82 Id. at $5-6$.

83 Another way to look at the "ISS effect" is to compare the difference in "against" votes 
Table 1. Say-on-Pay Votes (ISS Recommendations)

\begin{tabular}{|l|c|c|}
\hline \multirow{2}{*}{} & \multicolumn{2}{|c|}{ ISS recommendation } \\
\cline { 2 - 3 } & For & Against \\
\hline Votes "For" & $92.6 \%$ & $64.4 \%$ \\
\hline Votes "Against" & $6.7 \%$ & $34.9 \%$ \\
\hline Number of ISS Recommendations & 1324 & 173 \\
\hline Number of Failed Votes & 0 & 31 \\
\hline
\end{tabular}

However, a negative ISS recommendation does not necessarily mean that the company will get less than majority support for its sayon-pay proposal. In fact, we find that in only thirty-one cases in our sample did companies "fail" their vote, by getting less than fifty percent approval from shareholders. In the other 142 cases where the ISS gave a negative recommendation, shareholders still gave at least majority support for the company's proposal. Even though a negative ISS recommendation was not sufficient for a company to fail its sayon-pay vote, such a recommendation appeared necessary for a failed vote.

We also looked at how ISS recommendations affected shareholder voting on the frequency with which companies proposed to conduct their say-on-pay votes. Table 2 below shows that ISS almost always recommended in favor of annual say-on-pay votes and that shareholders strongly supported annual voting. Overall, shareholders at 1347 companies in our sample (by majority or plurality vote) supported annual say-on-pay voting, compared with shareholders at only 123 companies supporting triennial voting. In other words, say-on-pay promises to be an annual event at most larger public companies.

depending on whether the ISS gives a positive or negative recommendation. Here, the ISS effect is $28.2 \%$.

The ISS effect we find in the post-Dodd-Frank period is somewhat higher than the ISS effect we found for say-on-pay votes in the pre-Dodd-Frank period, where we found a $19.0 \%$ ISS effect when the ISS gives a "for" recommendation. Thomas, Palmiter \& Cotter, supra note 1, at 1245 tbl.4. 
Table 2. Advisory Vote on Say-on-Pay Frequency

\begin{tabular}{|l|c|c|c|}
\hline & \multicolumn{3}{|c|}{ ISS Recommendation } \\
\cline { 2 - 4 } & "For" One Year & Do Not Vote & $\begin{array}{c}\text { Companies } \\
\text { Adopting }\end{array}$ \\
\hline "For" One Year & $72.0 \%$ & $87.4 \%$ & 1347 \\
\hline "For" Two Years & $2.1 \%$ & $4.7 \%$ & 4 \\
\hline "For" Three Years & $25.9 \%$ & $7.9 \%$ & 123 \\
\hline Number of Votes & 1347 & 6 & \\
\hline
\end{tabular}

Again, ISS recommendations were influential (but not decisive) in how shareholders voted on the frequency question. At 377 companies in our sample where management recommended biennial or triennial say-on-pay voting, shareholders voted consistently with the ISS recommendation for annual voting in 254 of the companies. Yet at 123 companies ( $8.2 \%$ of our sample), shareholders adopted biennial or triennial voting despite an ISS recommendation for annual voting.

\section{B. Effect of Other Factors on Say-on-Pay Voting}

What other factors-besides an ISS recommendation-affected shareholder say-on-pay voting in the 2011 proxy season? We used our dataset to test for three factors widely identified by the ISS, commentators, and other studies as driving say-on-pay-namely, company stock performance, growth in CEO pay levels, and "excess" CEO pay.

\section{Effect of "Total Stock Return"}

The ISS and The Conference Board have both identified pay-forperformance issues as a principal reason for negative shareholder sayon-pay votes. ${ }^{84}$ According to the ISS's 2011 U.S. Postseason Report, of the companies it examined, "[a]lmost half of the failed-vote firms have reported double-digit negative three-year total shareholder returns." 85 In the same report, ISS noted (though not as prominently)

84 AlLEN ET AL., supra note 65, at 7 (explaining that "pay-for-performance concerns" seemed to represent "[t]he primary driver of [the] failed votes . . at 28 companies"); Russell Miller \& Yonat Assayag, SOP Drives Compensation Program Changes to Enhance Pay/Performance Link, DiREcTOR NOTES, 4 (Sept. 2011), https://www.conference-board.org/retrievefile.cfm?filename=TCB-DN-V3N18-11.pdf \& type=subsite. For example, "[a]t Constellation [Energy], shareholder support [for company pay practices] was only 38.6 percent," as the CEO's "total compensation increased from $\$ 6.7$ million in 2009 to almost $\$ 16$ million in 2010," despite "one-year and three-year total shareholder returns [of] negative 10.3 percent and negative 30.6 percent, respectively." Allen ET AL., supra note 65, at 7.

85 Allen ET AL., supra note 65, at 3. Jeremy Goldstein of Wachtell, Lipton, Rosen \& Katz also identified certain pay practices as likely to trigger a negative ISS voting recommendation. Jeremy L. Goldstein, How to Win the Say on Pay Vote, Harvard L. SCH. F. on Corp. Govern- 
the relevance of other compensation issues- "such . . . as tax grossups, discretionary bonuses, inappropriate peer benchmarking . . . and failure to address significant opposition to compensation committee members in the past." ${ }^{86}$

Given the importance that shareholders seemed to attach to company performance in their say-on-pay voting, we looked at how company total stock returns ("TSR") (defined as the cumulative raw return of the company's stock in the twenty-four months prior to Fiscal Year End 2010) and ISS recommendations correlated with shareholder votes. As Table 3 shows, TSR is a strong predictor of say-onpay voting-strong TSRs correlate with high levels of shareholder support and weak TSRs correlate with low levels of shareholder support. ${ }^{87}$ We group companies in our Study by quintile based on their TSR over two years, with the weakest performers in Group 1 and the strongest in Group 5. We see that a negative ISS recommendation has the biggest impact for Group 1 (the weakest TSR quintile), where sayon-pay proposals received only $62.8 \%$ average voting support, compared to Group 5 (the strongest TSR quintile), where the proposals averaged $68.9 \%$ voting support. These differences are statistically significant at the $1 \%$ level of significance.

ANCE AND FIN. REG. (Dec. 1, 2011, 9:31 AM), http://blogs.law.harvard.edu/corpgov/2011/12/01/ how-to-win-the-say-on-pay-vote/.

86 Allen ET AL., supra note 65, at 7. A publication examining "the first 100 proxy filings by Fortune 500 companies . . . subject to shareholder advisory votes under [Dodd-Frank]" by The Conference Board claimed that such other matters did not have a large impact on shareholder votes. Miller \& Assayag, supra note 84, at 1,5. The publication noted that "[a] study of four compensation practices . . .-excise tax gross-ups, perquisites, stock ownership guidelines, and clawbacks-indicates that [say-on-pay] votes for companies with those pay practices did not significantly differ from companies without them." Id. at 5 . The study later acknowledged, however, that "when combined with other shareholder concerns (such as a pay and performance disconnect), there is the potential for these practices to swing the vote." Id.

87 See Subodh Mishra, Institutional S'holder Servs. Inc., Parsing the Vote: CeO Pay Characteristics Relative to Shareholder Dissent 4 (2012), available at http:// www.isscorporateservices.com/node/22034/done?sid=3815; Miller \& Assayag, supra note 84, at 4 . 
Table 3. SAy-on-Pay Votes (Relation to TSR)

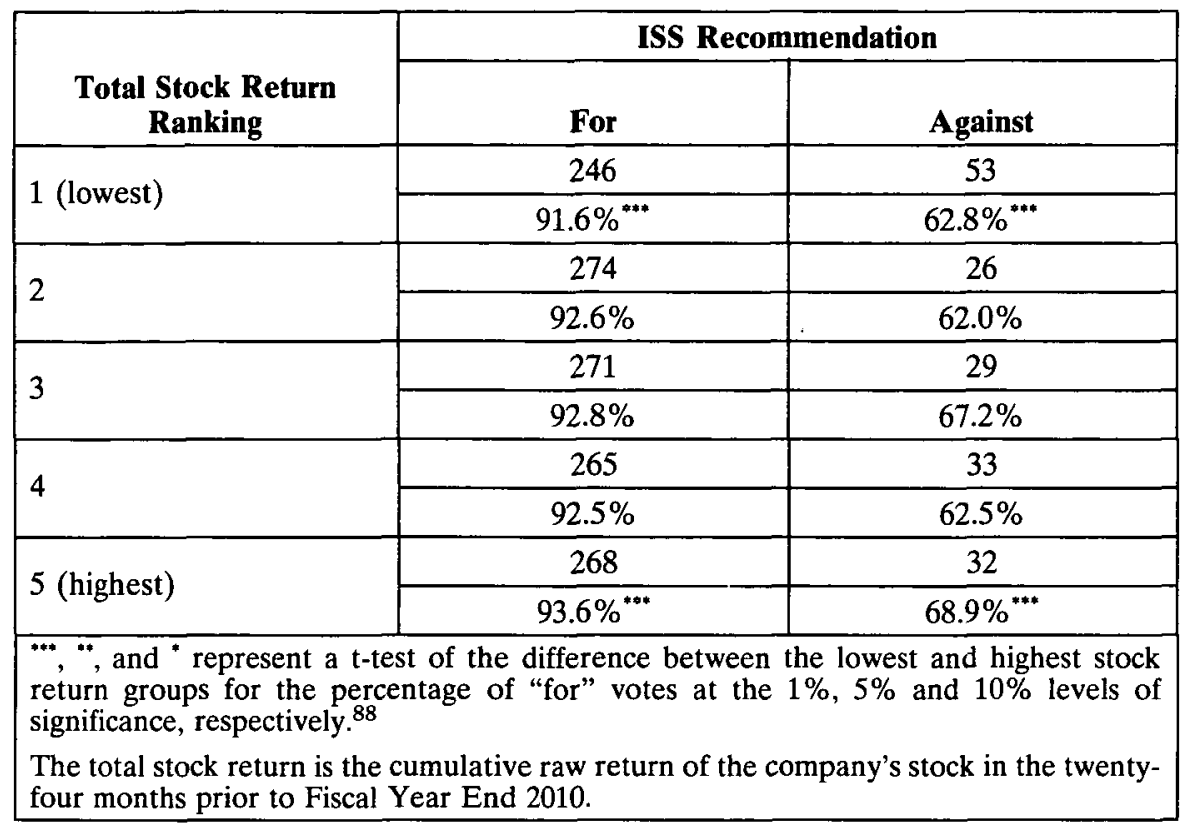

Thus, TSR had a small (but statistically significant) effect when the ISS gave a "for" voting recommendation, with shareholders giving $2.0 \%$ more voting support for pay at companies with the highest TSRs than for pay at companies with the lowest TSRs. In addition, a larger effect (also statistically significant) was present when the ISS gave an "against" recommendation, with shareholders giving $6.1 \%$ higher support for pay at high-TSR companies than for pay at low-TSR companies. In short, TSR had an effect on shareholder say-on-pay voting, although less than that of the ISS recommendation.

Our finding that short-term TSR performance was a factor in shareholder voting support, but was not outcome determinative, is borne out by other studies. For example, an Equilar study of say-onpay in 2011 found that "among those companies receiving greater than 90 percent approval, over 20 percent still had a bottom-quartile TSR ranking." ${ }^{89}$ Nonetheless, performance results were important, as demonstrated by the figure below from the Equilar study, which shows a "distribution of companies by performance that fall into each voting bracket for one-year total shareholder return":90

88 For a discussion of t-tests and levels of significance, see ROBERT S. PINDYCK \& DANIEL.

L. Rubinfield, Econometric Models and Economic Forecasts 36-39 (1981).

89 EQUILAR, INC., supra note 65 , at 2.

90 Id. at 2-3. 
Figure. Shareholder Say-on-Pay Approval BY ONE-YEAR TSR QUARTILE ${ }^{91}$

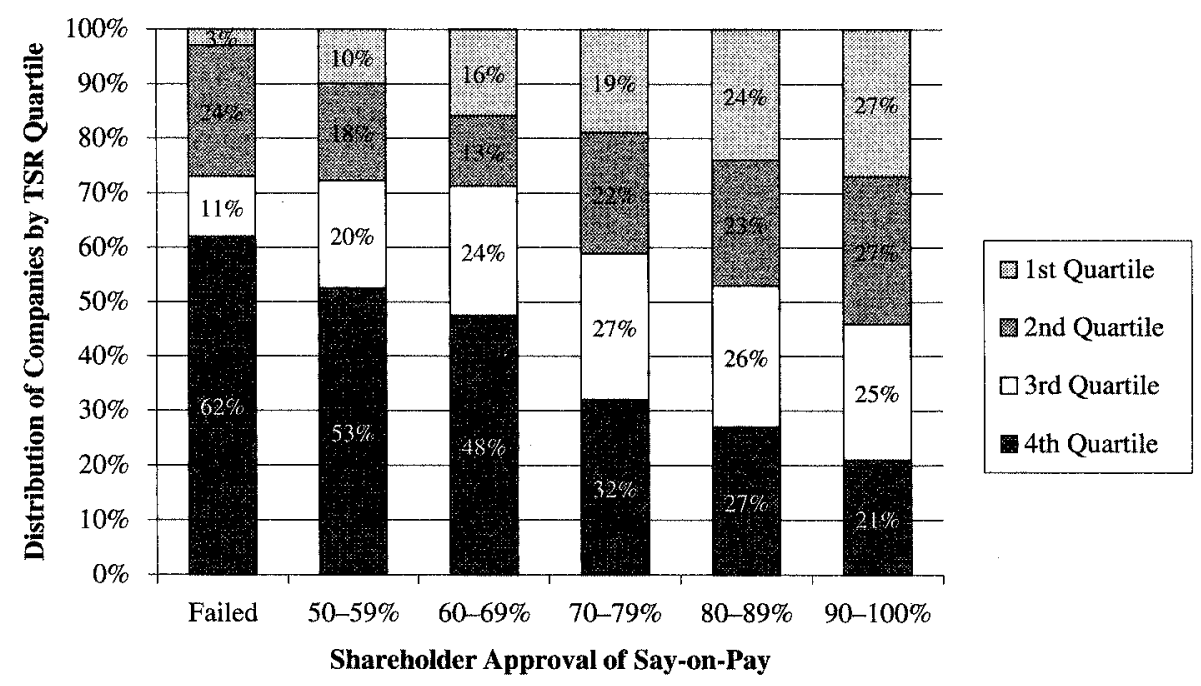

\section{Effect of CEO Pay Growth}

Other studies of say-on-pay voting suggest that increases in CEO pay may have been important in say-on-pay voting. ${ }^{92}$ In addition, proxy advisory firms have considered one-year pay growth in analyzing pay practices, recommending negative votes more often at companies with above average CEO pay increases than at those with belowaverage CEO pay increases. ${ }^{93}$

In Table 4, we show the effect of CEO pay growth on shareholder say-on-pay support. ${ }^{94}$ Companies with the highest rates of CEO pay growth are in Group 5, while those with the lowest rates of growth are in Group 1. Overall, these results show that higher growth rates are associated with lower levels of shareholder support. The differences are statistically significant at the $5 \%$ level when ISS makes a "for" recommendation, but the differences are not markedly different (nor statistically significant) when the ISS makes an "against" recommendation.

91 This Figure is a reproduction of a figure appearing in the Equilar study. See id.

92 See, e.g., Miller \& Assayag, supra note 84, at 4.

93 See id. at 5.

94 We first calculated total annual compensation for each calendar year, drawn from the company's "total compensation table" found in its proxy statement. We then used those values to calculate percentage change in annual compensation values. 
Table 4. Say-on-Pay Votes (Relation to Pay Growth)

\begin{tabular}{|l|c|c|}
\hline \multirow{2}{*}{ Pay Growth Ranking } & For & ISS Recommendation \\
\cline { 2 - 3 } 1 (lowest) & 254 & 22 \\
\cline { 2 - 3 } & $95.5 \% * *$ & $66.4 \%$ \\
\hline \multirow{2}{*}{2} & 258 & 17 \\
\hline \multirow{2}{*}{3} & $93.6 \%$ & $63.0 \%$ \\
\hline \multirow{2}{*}{4} & 258 & 18 \\
\cline { 2 - 3 } & $93.0 \%$ & $67.5 \%$ \\
\hline \multirow{2}{*}{5 (highest) } & 236 & 39 \\
\cline { 2 - 3 } & $92.0 \%$ & $65.1 \%$ \\
\hline \multirow{2}{*}{$\begin{array}{l}\text { ** represents a t-test of the difference between the lowest and highest pay growth groups } \\
\text { for the percentage of "for" votes at the 5\% level of significance. }\end{array}$} \\
\hline
\end{tabular}

Based on these univariate results, CEO pay growth does not appear to have as decisive an effect on shareholder say-on-pay voting as some have said. Although CEO pay growth had a negative effect on say-on-pay votes, this happened only when the ISS gave a "for" voting recommendation. Specifically, in the face of a positive ISS voting recommendation, shareholders gave $7.3 \%$ less voting support in the highest pay-growth companies compared to the lowest pay-growth companies. But when the ISS gave an "against" voting recommendation, there was no statistically significant difference in the voting results, although there was about a $3.6 \%$ lower average vote at companies with high levels of growth of CEO pay compared to companies with low levels of growth of CEO pay. In short, shareholders seemed less focused on CEO pay growth compared to company TSR.

\section{Effect of "Excess" CEO Pay}

Commentators and studies have identified perceived "excess" in CEO pay - that is, pay above the level predicted by a variety of variables-as a factor in say-on-pay voting. ${ }^{95}$

In Table 5, we examine the effect of "excess" CEO pay levels on shareholder support. Excess CEO pay attempts to measure the difference between actual pay levels and expected pay levels, based on an estimated value using several variables. ${ }^{96}$ We see in Table 5 that com-

95 See, e.g., Thomas, Palmiter \& Cotter, supra note 1, at 1221-22 (citing Ertimur, Ferri \& Muslu, supra note 41 ).

96 The definition of "Excess Pay" follows the "measure of excess CEO compensation," 
panies with the highest levels of excess CEO pay also receive the lowest levels of shareholder say-on-pay support. The differences between the first and the fifth quintiles are statistically significant at the $1 \%$ level for "for" votes, but again (as with growth of CEO pay) not markedly different for "against" votes.

\section{Table 5. Say-on-Pay Votes (Relation to "Excess" CEO Pay)}

\begin{tabular}{|l|c|c|}
\hline \multirow{2}{*}{ Excess Pay Ranking } & For & ISS Recommendation \\
\cline { 2 - 3 } \multirow{2}{*}{1 (lowest) } & 254 & 22 \\
\cline { 2 - 3 } & $95.5 \% * * *$ & $66.4 \%$ \\
\hline \multirow{2}{*}{2} & 258 & 17 \\
\cline { 2 - 3 } & $93.6 \%$ & $63.0 \%$ \\
\hline \multirow{2}{*}{3} & 258 & 18 \\
\hline \multirow{2}{*}{4} & $93.0 \%$ & $67.5 \%$ \\
\hline \multirow{2}{*}{5 (highest) } & 236 & 39 \\
\cline { 2 - 3 } & $92.0 \%$ & $65.1 \%$ \\
\hline \multirow{2}{*}{ Average Support } & 211 & 65 \\
\hline \multirow{2}{*}{$\begin{array}{l}* \\
\text { gropresents a t-test of the difference between the lowest and highest "excess" CEO pay }\end{array}$} \\
\cline { 2 - 3 } & $88.2 \% * * *$ & $62.8 \%$ \\
\hline
\end{tabular}

Like TSR and CEO pay growth, excess CEO pay is a factor in shareholder say-on-pay voting-but only when the ISS gives a "for" recommendation. For companies with the highest "excess" CEO pay, shareholders give $7.3 \%$ less support than for companies with the least "excess" CEO pay-an effect much smaller than for an ISS voting recommendation.

In short, our univariate analysis demonstrates that an ISS "against" recommendation seems to dominate shareholder say-on-pay voting, overshadowing the effects of TSR, CEO pay growth, and excess CEO pay. Only when the ISS gives a "for" recommendation do shareholders do their own homework and withdraw some of their vot-

John E. Core et al., The Power of the Pen and Executive Compensation, 88 J. Fin. Econ. 1, 11 (2008), and is equal to the natural logarithm ("log") of total compensation minus expected log (compensation), where expected log (compensation) is estimated by regressing log (total compensation) on a series of independent variables for the full sample, which include log (tenure of executive), log (sales), S\&P 500 return, book-to-market ratio, stock return in 2010 , stock return in 2009 , return on assets in 2010 , return on assets in 2009 , and industry control indicator variables, see id. at 11-12. The value for expected log (total compensation) is the residual using the parameter estimates from the regression applied to each firm. See id. at 12. 
ing support when a company has high TSR, high CEO pay growth, or high CEO excess pay.

\section{Multivariate Analysis: Sorting out Factors}

Given the apparent strength of an ISS say-on-pay recommendation, particularly when it is negative, we next seek to sort out the relevance of the factors examined in Tables 3,4 , and 5 (total stock returns, growth of CEO pay, and "excess" CEO pay) and to sort out their individual strengths compared to the impact of an ISS "against" recommendation.

In Table 6, we show the results of an ordinary least-squares linear regression on the variables identified in Tables 3, 4, and 5.97 In particular, we used the percentage vote on say-on-pay frequency as the dependent variable and looked at the following independent variables: (1) negative ISS recommendation, (2) excess CEO pay, (3) percentage change in CEO pay, and (4) an interaction term for companies that are both in the highest quintile for excess pay and the lowest quintile for total stock return (that is, the worst performing companies with the most excessively-paid CEOs).

We find that all of these independent variables are negative factors in say-on-pay votes and statistically significant, except for percentage change in CEO pay, which was insignificant. However, we also find (as our univariate analysis suggested) that an ISS "against" recommendation is much more relevant to shareholder voting than the "excess" pay and combined low TSR/high excess pay factorseven dwarfing them in predictive value.

97 A linear regression seeks to identify the impact of an input variable (also called a dependent variable) on an output variable (also called an independent variable). For further discussion of ordinary least-squares linear regression, see JaN KMENTA, Elements of ECONOMETRICs 350-53 (1971). In this case, we are measuring the impact of an ISS "against" recommendation on say-on-pay voting, and we find that an ISS "against" recommendation decreases the percentage of "for" votes on the say-on-pay proposal by $26.7 \%$. 


\section{Table 6. Multivariate Regression}

\begin{tabular}{|c|c|}
\hline Intercept $^{98}$ & $0.929^{* * *}$ \\
\hline Variables & Coefficient \\
\hline ISS Recommendation ("Against") 99 & $-0.267^{* * *}$ \\
\hline "Excess" Pay 100 & $-0.020^{* * *}$ \\
\hline Percentage Change in Pay ${ }^{101}$ & 0.000 \\
\hline Lowest TSR Rank ${ }^{*}$ Highest Excess Pay Rank ${ }^{102}$ & $-0.005^{* *}$ \\
\hline Adjusted R squared & 0.557 \\
\hline
\end{tabular}

These results support the conclusion that shareholders seemed to be influenced in their first year of say-on-pay voting by an ISS "against" recommendation far more than shareholders' own analysis of whether the company was an outlier in terms of high overall pay or low total stock returns compared to the company's industry or peers. This analysis suggests that the ISS may be identifying the principal factors that shareholders find relevant in their say-on-pay votes-or that shareholders believe the IȘS has done this for them.

The analysis also suggests that shareholders on their ownthough to a lesser extent than the ISS-identify some outlier companies based on their independent analysis of "excess" pay and its inter-

98 In a linear regression, the intercept is a constant representing the value of the independent variable (defined in supra note 97) irrespective of the impact of the dependent variables. See KMENTA, supra note 97 , at 5 . When other dependent variables are added to the regression, the impact of their addition is measured by the coefficient listed in each table. See generally id. at $347-50$. An indicator variable is a variable that is either 0 or 1 depending on whether the binary variable is a yes or no. See id. at 409-10,425-48. In this case, ISS either favors a say-on-pay proposal (indicator is 1) or opposes the proposal (indicator is 0 ). The coefficient then measures the impact of ISS favoring a proposal versus opposing the proposal. An interaction variable is a combination of two variables. See id. at 418-19. If ISS favors a proposal and the company's executive is highly paid, the interaction variable would be a 1 and a 0 otherwise.

99 ISS Recommendation is an indicator variable that is 1 if the ISS recommends against the proposal.

100 "Excess Pay" is computed using the methodology of John E. Core et al., supra note 96.

101 "Percentage Change in Pay" is a variable calculated by ExecuComp that represents the change in total compensation to the CEO of each firm scaled by total cash compensation in the prior fiscal year. Brian Cadman et. al., Determinants of CEO Pay: A Comparison of ExecuComp and Non-ExecuComp Firms, 85 ACCT. REv. 1511, 1540 (2010). ExecuComp is a source of data that provides standardized data on all facets of the compensation for the combination of the S\&P 500, S\&P 600, and S\&P 400. Id. at 1511. The data includes the value of cash, incentive, and option/stock compensation. Id.

102 "Lowest TSR Rank * Highest Excess Pay Rank" is an interaction variable that is 1 if a firm's twenty-four-month stock price return is in the lowest quintile and the firm's CEO's excess pay is in the highest quintile. 
action with TSR. Interestingly, the claim that growth in CEO pay has independent predictive value in identifying outlier companies (something suggested in our univariate analysis) is not supported by our multivariate analysis of the data. In all, the ISS identification of outlier companies through an "against" voting recommendation and the further identification of outliers by shareholders (beyond that contained in a negative ISS recommendation) based on a combination of company "excess" pay and company TSR seem to explain how sayon-pay was used in its inaugural year to identify and discipline pay practices at outlier firms.

Nonetheless, the factors we looked at were less than fully explanatory of say-on-pay voting in the first year under Dodd-Frank. The strength of a negative ISS recommendation was clear, but not completely explanatory of say-on-pay voting. Additional tested factorslow TSR (poor stock performance) and combined low performance/ excess pay-were relatively weaker in explaining shareholder say-onpay voting. In short, it appears there may be other factors neither identified by our analysis nor suggested by others that may also be important in shareholders' voting decisions.

\section{Say-On-Pay in 2012 Proxy Season}

Some commentators have described the 2011 proxy season as a watershed event in U.S. corporate governance. They have concluded that mandatory say-on-pay voting under Dodd-Frank brought about greater management attention to shareholder concerns generally, increased shareholder interest in voting on corporate governance, and catalyzed a broader shareholder-management dialogue on pay issues-a dialogue that included proxy advisory firms. ${ }^{103}$ As one sayon-pay proponent explained:

(a) say-on-pay brings greater attention to executive pay policies and practices; (b) shareholders feel more connected with the process of setting executive pay ...; and (c) directors and management give increased attention to whether executive pay is consistent with shareholders' views. ${ }^{104}$

103 See Luis A. Aguilar, Comm'r, Sec. \& Exch. Comm'n, An Inflection Point: The SEC and the Current Financial Reform Landscape, Speech Before the Social Investment Forum 2011 Conference (June 10, 2011), available at http://www.sec.gov/news/speech/2011/ spch061011laa.htm.

104 Joseph E. Bachelder III, Say-on-Pay Under Dodd-Frank, Harvard L. Sch. F. oN Corp. Governance \& FIN. Reg. (Sept. 17, 2011, 8:19 AM), http://blogs.law.harvard.edu/ corpgov/2011/09/17/say-on-pay-under-dodd-frank/. 
But say-on-pay voting during the 2011 proxy season did not lead, as some had predicted, to a widespread shareholder backlash against increasing levels of executive pay. Although the ISS evaluated sayon-pay proposals, in part, based on whether inappropriate "peer group benchmarking" had been "used to set target pay or award opportunities," 105 the upward spiral in CEO pay seemed not to be on the minds of most shareholders. ${ }^{106}$ Our analysis demonstrates that growth in CEO pay was not a strong factor in explaining negative say-on-pay votes. ${ }^{107}$

As interesting as say-on-pay voting was during the 2011 proxy season, the aftermath of the first year of say-on-pay has been perhaps more interesting. We next look at commentary on say-on-pay before and during the 2012 proxy season. We then examine how say-on-pay has affected recent pay practices-and corporate governance dynamics-at four targeted companies. We find that say-on-pay in 2011 appears to have been the beginning of a trend in which the ISS and institutional shareholders have taken a much larger role in setting the agenda for executive pay in U.S. companies.

\section{A. Getting Ready for Say-On-Pay in 2012: Aftermath of 2011}

Companies during the first proxy season of say-on-pay in 2011 awoke to the new realities of shareholder interest in executive pay. Generally, companies responded with increased (and different) disclosures and became proactive in the face of a negative ISS voting recommendation. Shareholders also behaved differently, paying attention to new company outreach and focusing their attention on the say-on-pay vote rather than other avenues to communicate their views on pay practices. The failure by companies to address shareholder concerns, sometimes leading to a failed say-on-pay vote, often resulted in litigation. Proxy advisors took note of these developments, schooling their company clients on how to avoid say-on-pay failure.

\section{Company Responses to Say-on-Pay in 2011}

Even before say-on-pay voting began during the 2011 proxy season, management at many companies changed the substance and dis-

105 See InSTITUTIONAL S'HOLDERs SERvs. INC., supra note 75, at 38.

106 Note that Cheffins \& Thomas in 2001 highlighted the concerns of some who had "observed that shareholder monitoring is only suitable for addressing occasional problems with executive pay practices." Cheffins \& Thomas, supra note 51 , at $310-11$.

107 See supra Table 6. 
closure of their pay programs. ${ }^{108}$ According to a study by The Conference Board on pay practices at the first 100 companies in the Fortune 500 to file their 2011 proxy filings, many of these companies revised their pay programs, particularly to more clearly align pay with performance. ${ }^{109}$ Many companies also changed their CD\&A disclosures of executive pay filed with annual meeting proxy materials. ${ }^{110}$

In addition, some companies before the 2011 proxy season revised their executive pay programs by "minimizing non-performancebased pay" ("such as tax gross-ups, executive perquisites and large severance arrangements") or improving the relationship between pay and performance. ${ }^{111}$ According to The Conference Board, forty-six percent of the companies in their study "eliminated [or reduced] nonperformance-based pay elements" in anticipation of the 2011 say-onpay vote. ${ }^{112}$ The Conference Board found that six companies improved the pay-for-performance relationship with changes to company guidelines on CEO stock ownership ${ }^{113}$ and thirty-four others revised standards for "clawbacks" (restitution) of executive pay after a financial restatement. ${ }^{114}$

Also before say-on-pay voting during the 2011 proxy season, many companies revised their proxy disclosure of executive pay, seeking to make the disclosure not only compliant, but also informative and persuasive. Many companies "us[ed] the CD\&A to tell their story and provide a clear business rationale for their compensation decisions." 115 Most companies in The Conference Board study (sixtyfive, up from thirty the year before) included "executive summaries on their pay-for-performance relationships," frequently with useful

108 See Miller \& Assayag, supra note 84, at 1-3.

109 Id. at $1-2$.

$110 \mathrm{Id}$. at $2-3$.

111 Id. at 2.

112 Id. The Conference Board study reported that "[n]early 40 companies . . eliminated excise tax gross-ups (either from existing or future arrangements)," that "[t]en [companies] ... reduced or eliminated perquisites, such as country club memberships and financial planning," and that "[t]hree companies reduced severance multiples for the CEO from three [times] cash compensation to two [times]." Id.

113 Id. These six companies in 2010 changed their "CEO stock ownership guideline[s]" to specify a range of six to ten times salary, rather than the more common five times salary. Id.

114 Id. "Under Dodd-Frank, companies will be required to enhance 'clawback' standards ...." Id. In anticipation of these changes, companies changed their clawback provisions through measures like "expand[ing] the list of executives subject to clawbacks and expand[ing] the items subject to clawbacks for the broader executive group." Id. (explaining that of the "80 companies disclosing clawback provisions . . ., 34 recently adopted or enhanced these provisions").

115 Id. 
graphical representations. ${ }^{116}$ Some companies went so far as to include a summary at the beginning of the proxy statement that emphasized pay determinations and firm performance in $2010 .{ }^{117}$

\section{Company (and Shareholder) Responses to Negative ISS Recommendations in 2011}

A remarkable aspect of the 2011 proxy season was the give and take that occurred at companies that received negative say-on-pay recommendations by the proxy advisory firms. Rather than counting on shareholder loyalty, management at these companies entered into a direct dialogue with shareholders following the "against" recommendation. ${ }^{118}$

As one commentator noted, "With additional pressure from proxy-advisory firm recommendations, the new law has led many companies to increase their communication with shareholders and reevaluate their compensation and corporate-governance practices."119 In addition, some companies receiving a negative recommendation filed supplemental proxy disclosures "in large part to defend their pay-for-performance orientation," 120 including "slideshow presentations," "letters to proxy advisory firms ... tak[ing] issue with the accuracy of the information cited in the reports or disagreeing with the analysis," and "letters to shareholders."121 Management engagement with shareholders seemed to bear fruit. Many companies that responded to an ISS "against" recommendation with additional disclosure eventually received a favorable say-on-pay vote..$^{122}$

Yet some companies that received negative say-on-pay recommendations during the 2011 proxy season "were unprepared and were unable to quickly ramp up their shareholder outreach." 123 The com-

116 Id. For example, some companies included "a comparison of total shareholder return (TSR) vs. CEO pay at the beginning of the CD\&A," possibly anticipating a pending requirement under new SEC rules. Id. at 3. Other companies included in the CD\&A comparisons of company TSR with "the TSR of an index and peers over a multiyear period"ready required under Form 10-K. Id.

117 Id.

118 See Thomas, Palmiter \& Cotter, supra note 1, at 1258-59; EOUILAR, InC., supra note 65, at 1; Littenberg, Damania \& Neidig, supra note 72, at 6.

119 Equilar, InC., supra note 65, at 1.

- 120 Miller \& Assayag, supra note 84, at 3 (reporting such action at seven of the first one hundred Fortune 500 companies to file proxy materials in 2011).

121 Littenberg, Damania \& Neidig, supra note 72, at 6.

122 See Miller \& Assayag, supra note 84, at 3.

123 Littenberg, Damania \& Neidig, supra note 72, at 6 (explaining that a number of companies failed to analyze shareholder demographics or send a clear message). 
panies were often advised that they could "be at risk" of a future unfavorable recommendation or vote and should "hone their messaging and outreach strategy well in advance of next year's annual meeting." 124

Reviewing the aftermath of the 2011 proxy season, the ISS commented that say-on-pay seemed to have changed the shareholdermanagement dialogue, with shareholders resorting less often in 2011 to "no" or "withhold" votes on directors. ${ }^{125}$ In other words, rather than express displeasure with executive pay by voting against particular directors, shareholders used the say-on-pay vote to voice their opinions about pay practices.

This explanation of the 2011 proxy season was substantiated by the results of director elections. As some commentators noted, directors up for election in 2011 were "re-elected with the highest average level of shareholder support in the last five years." 126 While ninetyone directors in 2010 and ninety-three directors in 2009 failed to receive majority shareholder backing, the number of directors failing to receive such support in 2011 dropped to forty-five. ${ }^{127}$ To the extent that shareholders voted against individual directors, reasons other than membership on a controversial compensation committee dominated their reasons for not reelecting directors, including "poor meeting attendance," "failure to put a poison pill to a shareholder vote," and "failure to implement majority-supported shareholder resolutions." 128

Nonetheless, this diversion of shareholder attention during the 2011 proxy season away from directors did not happen for directors on the compensation committees at companies with failed say-on-pay votes. In one study, such directors "received, on average, $13.5 \%$ fewer votes in favor than the other directors on the ballot." ${ }^{29}$ By con-

124 Id.; see also Thomas, Palmiter \& Cotter, supra note 1, at 1259.

125 Allen ET AL., supra note 65, at 14. This pattern was in line with ISS voting guidelines for 2011, which called on shareholders to express "dissatisfaction with compensation practices ... by voting against [management's say-on-pay proposal] rather than withholding or voting against the compensation committee.” 2011 U.S. Proxy Voting Guidelines Summary, supra note 75, at 37. But when management did not offer a say-on-pay proposal, the ISS suggested that a "negative vote will apply to members of the compensation committee." Id.

126 Littenberg, Damania \& Neidig, supra note 72, at 5 (relying on "data attributed to ISS" and citing Barry Burr, Say-on-Pay Shifting Proxy Focus, Pensions \& Investments (June 13, 2011), http:/www.pionline.com/article/20110613/PRINTSUB/306139971).

127 ALLEN ET AL., supra note 65, at 30 (noting that this data refers to elections "through Sept. 1" in each of these years).

128 Id. at 2.

129 Littenberg, Damania \& Neidig, supra note 72, at 5. 
trast, the same study found only $2.4 \%$ fewer votes for directors sitting on compensation committees at "companies that received a negative ISS recommendation but had a passing [say-on-pay] vote."130 No doubt, compensation committee directors at firms with failed say-onpay votes took note, as "ISS has indicated that it may recommend a vote against" the reelection of such members "if the company has not addressed [ISS say-on-pay] concerns." 131

\section{Shareholder Litigation Following Failed 2011 Say-on-Pay Votes}

Dodd-Frank specifically disclaimed that its say-on-pay regime established new fiduciary duties for corporate directors. Even so, failed say-on-pay votes during the 2011 proxy season nevertheless spawned shareholder suits. ${ }^{132}$ Of the firms with a failed say-on-pay vote in 2011 , at least nine were targeted in lawsuits alleging breaches of director fiduciary duties and corporate waste. ${ }^{133}$ However, the proportion of firms sued after a failed say-on-pay vote in 2011 was lower than in 2010 , when "two of the three negative say-on-pay votes resulted in derivative actions." 134

These actions generally have claimed that the company in question "violated its 'pay for performance' philosophy" and that company directors violated their fiduciary duties by "disregard[ing] the negative advisory shareholder [say-on-pay] vote in failing to rescind the increased executive compensation." 135 Although some predicted that

$130 \mathrm{Id}$. (noting that for these results, the authors used a "random sample of $30 \ldots$ companies that received a negative ISS recommendation[] but had a passing [say-on-pay] vote").

131 Id.

132 William Alan Nelson II, Ending the Silence: Shareholder Derivative Suits and Amending the Dodd-Frank Act so "Say On Pay" Votes May Be Heard in the Boardroom, 20 U. Miami Bus. L. Rev. 149, 155-56 (2012); see also Kenneth B. Davis, Jr. \& Keith L. Johnson, Say on Pay Lawsuits-Is This Time Different?, Reinhart Headlines in Corp. Governance \& Investor Relations Servs. E-Alert 1 (Dec. 22, 2011), http://www.reinhartlaw.com/Publications/Documents/ea\%2020111221\%20BL.pdf.

133 Bachelder III, supra note 104, at 1 (reporting that "at least nine shareholder derivative actions . . . have been filed based on negative shareholder say-on-pay votes in 2011"); see also Jessica Lochmann Allen, Michael Schultz \& Steven Vazquez, The Impact of the 'Say-on-Pay' Vote on the CEO Evaluation Process, 9 Corp. ACCOunTABILITY ReP. (BNA) (Oct. 7, 2011), available at http://news.bna.com/caln/display/link_res.adp?lt=email\&fname=a0c9f7k8p3\&lf=eml \&emc-corb:caln:108 (referring to "at least nine companies to date . . facing state law derivative lawsuits" and stating that demand letters had been submitted to other companies, suggesting further litigation absent settlement).

134 Bachelder III, supra note 104, at 1 (stating that "[b]oth 2010 cases are reported to have been settled").

135 Allen, Schultz \& Vazquez, supra note 133 (reporting that some cases "allege that the negative shareholder vote itself was sufficient to rebut the . . business judgment rule"). 
such lawsuits would be dismissed as frivolous-which has happenedat least one court has denied a motion to dismiss, ${ }^{136}$ leading to questions about the "protection of the business judgment rule" in such cases. ${ }^{137}$

Fear of litigation following a failed say-on-pay vote led corporate advisors after the 2011 proxy season to recommend that companies change the "CEO performance evaluation process," and "position the company more favorably" to avoid a negative vote or "to defend against such a lawsuit."138 Directors have also been advised to "be especially sensitive to the deliberative process leading up to pay decisions and the way in which that process is documented."139 Not only have directors at companies with failed say-on-pay votes been sued, but so too have "outside compensation consultants" for allegedly "aid[ing] and abett[ing] [director] breaches of the duty of loyalty" as well as purportedly breaching their consulting agreements. ${ }^{140}$ This risk may in turn lead to higher consulting fees and "stronger indemnification provisions" in consulting agreements with at-risk clients. ${ }^{141}$

\section{B. Say-on-Pay in 2012: Early Results}

The predictions and cautions that came after the 2011 proxy season proved to be spot-on in the 2012 proxy season. Commentators examining preliminary results early in the 2012 season have made several important observations: (1) most companies targeted by the ISS in 2011 had mostly eliminated "egregious" pay practices, including excessive executive perquisites, "'golden parachute' payment tax gross ups," and undue severance pay; ${ }^{142}$ (2) companies have been engaging with shareholders through increased disclosure in their CD\&A statements; (3) companies have used extra solicitation materials in reply to unfavorable ISS recommendations; (4) more firms have been making "preemptive changes to compensation policies and practices" following consultations with their shareholders and proxy voting advisors; and (5) there are increasing levels of communications between compa-

136 NECA-IBEW Pension Fund ex rel. Cincinnati Bell, Inc. v. Cox, No. 1:11-cv-451, 2011 WL 4383368 , at *5 (S.D. Ohio Sept. 20, 2011).

137 See, e.g., Laura G. Thatcher, 'Cincinnati Bell' and 'Beazer': What Do These Opposite Say-On-Pay Decisions Bode for the Future?, 26 CORP. Couns. WKLY. (BNA), Oct. 19, 2011, at 320.

138 Allen, Schultz \& Vazquez, supra note 133; see also Thomas, Palmiter \& Cotter, supra note 1 , at 1262 .

139 Littenberg, Damania \& Neidig, supra note 72 , at 6.

140 Id.

141 Id.

142 Barrall, Chung \& Crisp, supra note 67 , at 2. 
nies and their institutional shareholders. ${ }^{143}$ All of these constituted significant changes from prior practices at most companies. ${ }^{144}$

Directors were generally receptive to shareholders' views. ${ }^{145}$ Indeed, according to a 2011 PriceWaterhouseCoopers survey:

$72 \%$ of directors [surveyed] indicate that their boards would reconsider executive compensation-even when these votes pass-if there are indications of significant shareholder dissatisfaction.

It appears the voice of proxy advisory firms can affect a board's thinking - a presumption also supported by the fact that $24 \%$ of boards have increased board-level communications with proxy advisory firms during the last 12 months . . . . ${ }^{146}$

Moreover, $45 \%$ of the survey respondents indicated that they altered their CD\&A "to be more "plain English." "147

Regarding board-level communications, the survey found:

Many directors increased communications with stakeholders during the last year in response to the desire of various corporate constituencies for more dialogue with board members. The largest increase is seen in communications with employees (36\%), while $31 \%$ report an increase in communications with major shareholders. Just over one-quarter $(26 \%)$ report an increase in communications with analysts. As additional evidence supporting the evolution of boards' communication policies, nearly half $(47 \%)$ of directors say the board should have a role in communicating governance issues to major shareholders, and one-third (33\%) indicate the board should communicate governance issues to proxy advisory firms, as well as employees. ${ }^{148}$

Despite these precautions, as of June 2012, "[m]ore than twice as many public companies have failed their say-on-pay votes during the ongoing 2012 proxy season as did in 2011."149 Vote failure numbers

143 Che Odom, Wishes of Proxy Advisors, Investors Must Be Considered This Proxy Season, Experts Say, 10 Corp. Accountability ReP. (BNA), Jan. 20, 2012, at 54-55.

144 See id.; Barrall, Chung \& Crisp, supra note 67, at 2.

145 PriceWaterhouseCoopers Llp Ctr. For Bd. Governance, Annual Corporate Director Survey 2011 Findings: Boards Respond to Stakeholder Concerns 2-3 (2011), http://www.pwc.com/en_US/us/corporate-governance/assets/annual-corporate-director-survey2011.pdf.

146 Id. at 4.

147 Id. at 5.

148 Id. at 8.

149 Joyce, supra note 69 (citing data as of June 27, 2012). 
reached " 2.7 percent of [the] 1,875 companies in the Russell 3000 " that had reported their results as of June 27, 2012.150 Perhaps the highest profile failure was Citigroup, which went from ninety-three percent shareholder approval in 2011 to only forty-five percent in 2012.151 Citigroup, the first bank to have a failed say-on-pay vote, had previously passed two such votes without trouble. ${ }^{152}$ Some have commented that the outcome of the vote left the company with few good options for paying its CEO. ${ }^{153}$

Clearly, "companies had a 'tougher time' in 2012 than in 2011 on say-on-pay voting". ${ }^{154}$ However, the problems seem to be concentrated at a relatively small number of companies, as the mean shareholder support level for "companies in the S\&P 500 . . . report[ing] ... as of June 22, 2012" reached eighty-nine percent, while median support was ninety-five percent-both comparable to the support shareholders gave under say-on-pay in 2011.155

As in 2011, commentators have identified that the triggers for shareholder opposition remain a firm's total stock return and a lack of connection between pay and performance. ${ }^{156}$ Commentators have also focused on a failure "to link incentives to a company's long-term performance," or at least to explain those linkages. ${ }^{157}$ Supplemental proxy materials that attempt to clarify these linkages have become more common: while only "about 105 companies issued [such documents] in 2011," over 250 are expected to do so in 2012.158

150 Id:; see also Memorandum from Michael J. Segal, Jeannemarie O'Brien \& Jeremy L. Goldstein, Wachtell, Lipton, Rosen \& Katz, Say on Pay 2012, at 1 (June 28, 2012) [hereinafter "June 28, 2012 Wachtell Memo"] (reporting that "[a]s of June 25, 2012 . . 54 [companies] have failed their say on pay votes"). Wachtell also noted that four businesses failed both in 2011 and 2012. Id. at 1.

151 Joyce, supra note 69. Citigroup shareholders appeared upset that their CEO had received a large pay increase for the same time period in which the company's stock price dropped $44 \%$ forty-four percent. Id.

152 See Che Odom, Citigroup Shareholders Vote Down Executive Compensation Proposal, 74 Corp. L. Daily (BNA) (Apr. 18, 2012).

153 Steven M. Davidoff, Citigroup Has Few Options After Pay Vote, N.Y. Times Dealbook (Apr. 18, 2012), http://dealbook.nytimes.com/2012/04/18/citigroup-has-few-options-after-payvotel.

154 Mary Hughes, Winning Say-On-Pay Votes Gets Harder, Practitioners Say, 15 CorP. GovernanCE REP. (BNA) 75, 75 (July 2, 2012) (quoting "compensation consultant Steven Hall of Steven Hall \& Partners, New York").

155 June 28, 2012 Wachtell Memo, supra note 150, at 1.

156 See Joyce, supra note 69.

157 Id.

158 Id. 
As in 2011, commentators have concluded that ISS recommendations continue to play a key role in the say-on-pay voting process. ${ }^{159}$ As of June 22, 2012, ISS had given negative recommendations at $14 \%$ of S\&P 500 firms, and "[o]f [the] companies receiving unfavorable vote recommendations from ISS, $21 \% \ldots$ failed to receive majority support" for their say-on-pay proposals. ${ }^{160}$ This represents a slight uptick from 2011, when $12.4 \%{ }^{161}$ of companies received negative recommendations from the ISS, with only $13 \%$ of such companies failing their say-on-pay vote. ${ }^{162}$ Moreover, among the companies in 2012 that received negative ISS recommendations, the companies that "passed" their vote received "considerably lower margins than those receiving a favorable ISS recommendation." 163 One industry player calculates that an unfavorable ISS recommendation had a $30 \%$ negative impact on "average shareholder support" during the 2012 proxy season, lowering it from $95 \%$ to $65 \%$, which was said to constitute an additional "10\% increase over [2011's] correlation" 164 -that is, a $10 \%$ increase in "ISS effect" in 2012. These calculations compare to our finding of a $28.2 \%$ ISS effect in 2011 at companies receiving a negative ISS recommendation. ${ }^{165}$

Company advisors have been telling their clients that they need to take proactive measures to ensure passage of their say-on-pay proposals in 2012 and beyond. ${ }^{166}$ One law firm recommends that directors need to: understand where their executive pay practices diverge from those desired by shareholders and their proxy voting advisors; improve the quality of their disclosures (especially those related to performance-based pay); "[r]each out to [their] [s]hareholders"; and, if necessary, change their pay practices when shareholders raise reasonable objections. ${ }^{167}$

159 June 28, 2012 Wachtell Memo, supra note 150, at 1.

160 Id.

161 See Thomas, Palimter \& Cotter, supra note 1, at 1255 n.183 (citing data from Littenberg, Damania \& Neidig, supra note 72 , at 3, that refer to "2,225 Russell 3000 companies that held annual meetings between January 21, 2011 . . and June 17, 2011").

162 See Littenberg, Damania \& Neidig, supra note 72, at 3 (presenting the same data as discussed in supra note 161). These 2011 results are comparable to those we found in our sample, where $11.6 \%$ of companies received a negative ISS recommendation, and $17.9 \%$ of such companies failed their say-on-pay vote. See supra Part II.A.

163 June 28, 2012 Wachtell Memo, supra note 150, at 1.

164 Id. (referring "to a recent study by Pay Governance").

165 See supra Table 1.

166 See, e.g., June 28, 2012 Wachtell Memo, supra note 150, at 2.

167 Id. at 2-4. 


\section{Company Responses to Negative ISS Recommendations: Four Case Studies}

We next present four case studies detailing the impact of say-onpay on executive pay practices and the interaction between management and shareholders in this new environment. The four cases can be sorted into two categories: (1) companies that changed their pay packages in response to negative ISS reports, and (2) companies that pushed back against a negative ISS recommendation by appealing directly to shareholders in their proxy filings.

The first two cases, Shuffle Master and The Walt Disney Company, involve negative ISS recommendations and the company's decision to amend its pay packages. At Shuffle Master, the amendment was remedial and occurred after a failed shareholder vote, while at Disney, the amendment was preemptive and most likely warded off a negative shareholder vote. Shareholders of both companies ratified the say-on-pay proposals after the directors reduced executive pay.

The latter two cases, Adobe Systems and Huntington Bancshares, are examples of how companies are fighting back against negative ISS recommendations. At both companies, shareholders approved the say-on-pay proposals in 2012 despite the negative ISS recommendations.

\section{Case 1: Shuffle Master}

Shuffle Master, Inc. 168 "lease[s], license[s], and sell[s]" gaming devices, including table games, slot machines, and other casino-related products. ${ }^{169}$ The company is traded on the NASDAQ (SHFL) ${ }^{170}$ and as of the date of its 2011 proxy filing had a market capitalization of approximately $\$ 560$ million. ${ }^{171}$

In its 2011 proxy filing, Shuffle Master outlined the following pay structure for its interim CEO, David Lopez: a $\$ 260,000$ base salary; $\$ 110,742$ in stock awards; $\$ 141,102$ in options; $\$ 175,000$ in cash bo-

168 Shuffle Master, Inc. changed its name to SHFL Entertainment, Inc. in October, 2012, but this Article will refer to the company as "Shuffle Master," as it was known during the events described in this Section. Press Release, SHFL Entertainment, Shuffle Master Begins New Chapter as SHFL Entertainment (Oct. 1, 2012), available at http://ir.shufflemaster.com/Investors/News-and-Press/Press-Releases/Press-Release-Details/2012/Shuffle-Master-Begins-New-

Chapter-As-SHFL-Entertainment1131251/default.aspx.

169 Shuffle Master, Inc., Annual Report (Form 10-K) 5 (Jan. 5, 2012).

170 Id. at 22.

171 See, e.g., SHFL Entertainment, WALL ST. J. http://quotes.wsj.com/SHFL (last visited Apr. 1, 2013). 
nuses; and $\$ 8,067$ in "other"-for a total pay package of $\$ 694,911 .{ }^{172}$ Mr. Lopez's employment agreement also contained a "modified single trigger" provision, which effectively would have permitted Lopez to obtain significant benefits if he had voluntarily terminated the agreement. ${ }^{173}$

Shortly after the proxy statement was filed with the SEC, ISS issued a report advising Shuffle Master's shareholders to vote against Mr. Lopez's pay package due to the relative excess of the modified single trigger provision in his employment agreement. ${ }^{174}$ At the company's annual meeting on March 17, 2011, the shareholders rejected the package: $55.5 \%$ "against" and $44.5 \%$ "for." 175

In response to this failed advisory vote, the company deleted $\mathrm{Mr}$. Lopez's modified single trigger provision. In its February 3, 2012 proxy statement, the company stated:

\section{Say-on-Pay Advisory Vote}

At the March 17, 2011 Annual Meeting of Shareholders, the shareholders of the Company voted, on an advisory basis, against approval of the named executive officer compensation disclosed in our proxy statement dated as of February 4, 2011. The Company believes that the negative shareholder vote was a result of the issuance on February 17, 2011 of the ISS Proxy Advisory Services report (the "Report"), which contained a recommendation against such advisory vote based solely on the inclusion of the "modified single trigger" provision in the employment agreement of Mr. David B. Lopez, the Company's Executive Vice President and Chief Operating Officer, in effect at such time.

On May 24, 2011, the Company amended Mr. Lopez's employment agreement, with the primary change being the deletion of the provision that permits the termination of the employment agreement by Mr. Lopez and the receipt of certain benefits upon a "change of control" of the Company. Under the amended and restated employment agreement,

172 Shuffle Master, Inc., Definitive Proxy Statement 28 (Form DEF 14A) (Feb. 4, 2011).

173 See Shuffle Master, Inc., Current Report (Form 8-K) (May 24, 2011) (explaining that Mr. Lopez's employment agreement from February 16, 2011 contained a modified single trigger); see also Jones Day, 2009 Proxy Season Update: RiskMetrics FAQs Regarding Up. DATEd 2009 COMPENSATION Policies (2009), available at http:/www.jonesday.com/2009-proxyseason-update-riskmetrics-faqs-regarding-updated-2009-compensation-policies-01-30-2009/ (describing "so-called 'modified single-trigger' provisions ... that allow an executive to receive benefits upon a voluntary termination for 'any reason,' often during a window period, following the change in company ownership").

174 See Shuffle Master, Inc., Definitive Proxy Statement 26 (Form DEF 14A) (Feb. 3, 2012).

175 See Shuffle Master, Inc., Current Report (Form 8-K) (Mar. 17, 2011). 
Mr. Lopez may only terminate his employment agreement "for good reason" in the event of a change of control if there is also a material reduction in the nature or scope of his duties, responsibilities, authority, or position, including, but not limited to, removal or expulsion from the Board of Directors without Cause, as such term is defined within such agreement. These changes removed the "modified single trigger" mechanism referred to in the Report. ${ }^{176}$

At the company's annual meeting on March 15, 2012, Shuffle Master's shareholders voted in favor of its say-on-pay proposal with an $86.4 \%$ vote. ${ }^{177}$ This case illustrates how a company responded to a failed say-on-pay vote in 2011, in the end garnering strong shareholder support in the 2012 say-on-pay vote.

\section{Case 2: Disney}

The Walt Disney Company is one of the largest publicly-traded companies in America ${ }^{178}$ and also one of the highest-paying. ${ }^{179}$ The company trades on the New York Stock Exchange (DIS) and in 2012 had a market capitalization of approximately $\$ 92$ billion. ${ }^{180}$

In its 2011 proxy filing, Disney revealed that the employment agreements for its top executives contained tax gross-ups in the event of a change in control. ${ }^{181}$ Following the filing of the Disney proxy materials, ISS issued a report urging shareholders to vote against the pay packages to top Disney executives. ${ }^{182}$

Prior to its shareholders' advisory vote on the company's 2011 pay packages, the company received significant shareholder feedback expressing discontent with the gross-ups. ${ }^{183}$ In response and prior to

176 Shuffle Master, Inc., Definitive Proxy Statement 26 (Form DEF 14A) (Feb. 3, 2012).

177 Shuffle Master, Inc., Current Report (Form 8-K) (Mar. 20, 2012).

178 See The World's Biggest Public Companies, Forbes (Apr. 18, 2012), http:// www.forbes.com/global2000/ (listing The Walt Disney Company as number 121 on its list of "The World's Biggest Public Companies").

179 See Lisa Richwine, Disney Disputes Shareholder Report on CEO Pay, Role, REUTERS (Mar. 1, 2012), http://www.reuters.com/article/2012/03/01/us-disney-shareholdersidUSTRE8201XT20120301.

180 See DIS Stock Price Today-Walt Disney Co. Stock Quote, Wall Sr. J., http://quotes. wsj.com/DIS?mod=DNH_S_cq (last visited Sept. 11, 2012).

181 See The Walt Disney Co., Definitive Proxy Statement 50-51 (Form DEF 14A) (Jan. 28, 2011).

182 See Ronald Grover \& Rob Golum, Disney Cuts 'Change in Control' Payments for Top Officials, BLoomberg (Mar. 18, 2011), http://www.bloomberg.com/news/2011-03-18/disneyremoves-change-in-control-tax-payment-for-top-officials.html.

183 See The Walt Disney Co., Definitive Proxy Statement 27 (Form DEF 14A) (Jan. 20, 2012) [hereinafter Disney 2012 Proxy Statement]. 
the say-on-pay vote at its annual meeting, the company eliminated the gross-up provisions from the executives' employment agreements. ${ }^{184}$ In its 2012 proxy filing, Disney did not admit (as had Shuffle Master) that the negative ISS recommendation was most likely responsible for the negative feedback it received from shareholders, but it did say this:

\section{Fiscal 2011 Decisions}

The following is a discussion of specific decisions made by the Compensation Committee in fiscal year 2011 or with respect to fiscal year 2011 compensation for the named executive officers. In making its decisions, the Committee considered specific comments received from shareholders. In particular, in connection with the advisory vote on executive compensation to be presented at the 2011 Annual Meeting, the Company received feedback from the Company's shareholder base regarding its practice of providing tax protection for certain executives who are subject to excise taxes on compensation received on termination following a change in control. In light of this feedback and considering evolving market practices, the Compensation Committee, prior to the 2011 Annual Meeting, adopted a policy that it will not, without shareholder approval, include reimbursement for excise taxes payable by an executive upon termination following a change in control in any future agreements with executive officers, and no agreement with executive officers contains such a provision at this time. Except where the Committee received specific feedback from shareholders, the Committee did not speculate as to the motivations behind the advisory vote, which, with approximately $77 \%$ of shares present and eligible to vote approving the resolution, the Committee considered to be generally favorable. ${ }^{185}$

As the 2012 proxy materials indicate, Disney's preemptive revision of its executives' employment agreements resulted in a $77 \%$ shareholder advisory approval of the revised pay packages. ${ }^{186}$ This is an example of a company responding quickly to shareholder concerns and as a result obtaining a favorable outcome on its say-on-pay vote.

184 See id.; The Walt Disney Co., Definitive Additional Materials (Form DEF 14A) (Mar. 18, 2011); Grover \& Golum, supra note 182.

185 Disney 2012 Proxy Statement, supra note 183, at 27.

186 See The Walt Disney Co., Current Report 2 (Form 8-K) (Mar. 25, 2011). 


\section{Case 3: Adobe Systems}

Adobe Systems, Inc. is a leading maker of electronic "software and services used by creative professionals, marketers, knowledge workers, application developers, enterprises and consumers for creating, managing, delivering, measuring, optimizing and engaging with compelling content and experiences across multiple operating systems, devices and media."187 The company trades on the NASDAQ (ADBE) and in 2012 had a market capitalization of approximately $\$ 16$ billion. ${ }^{188}$

In its March 2012 proxy filing, Adobe proposed the following changes to its executive pay structure, in light of shareholder say-onpay feedback:

\section{Changes to Fiscal Year 2012 Compensation Program}

During fiscal year 2011, the Executive Compensation Committee took note of stockholder feedback about the effectiveness of our "pay-for-performance" philosophy, including that more than $50 \%$ of our executive officers' equity awards were delivered through time-based equity vehicles (including stock options). In response to this feedback, the Executive Compensation Committee took the following actions to rebalance the target equity award mix for our executive officers, including the NEOs [named executive officers], for fiscal year 2012 to link more of their target TDC [total direct compensation] to longer-term performance and risk outcomes:

- Eliminated the use of stock options (for all employees).

- Adjusted the equity award mix to increase the proportion of the overall award delivered through performance-based equity vehicles. Specifically, for fiscal year 2012, half of the equity awards granted to our executive officers consist of performance shares, with the other half consisting of time-based RSU awards.

- Continued to provide that the performance share awards would be earned based on our actual achievement as measured against multiple pre-established strategic and financial objectives, with a new requirement that $20 \%$ of each performance share award would be

187 Adobe Sys. Inc., Annual Report 3 (Form 10-K) (Jan. 22, 2013).

188 See ADBE Stock Price Today - Adobe Systems Inc. Stock Quote, WALL ST. J., http:// quotes.wsj.com/DIS?mod=DNH_S_cq (last visited Sept. 15, 2012). 
earned based upon a relative total stockholder return measure.

- Continued to set the aggregate target value of [CEO] Mr. Narayen's annual equity award to comprise approximately $80 \%$ of his target TDC opportunity, and the average aggregate target value of the annual equity awards for our other NEOs at approximately $78 \%$ of their target TDC." 189

The company's 2012 proxy filing revealed that in accordance with its revisions to its executive pay program to link pay targets to "longer-term performance and risk outcomes," most of its executives' packages were substantially based on the realization of equity awards; the CEO's "aggregate target" pay mix was $20 \%$ cash (base pay plus cash bonuses) and $80 \%$ equity (for a total estimated package of $\$ 10,825,110$ ), and on average for the "named executive officers," the "aggregate target" pay mix was $26 \%$ cash pay and $74 \%$ equity. ${ }^{190}$ However, despite the company's ostensible responsiveness to its shareholders' concerns, ISS issued a negative recommendation on the company's say-on-pay proposal. ${ }^{191}$

On April 2, 2012, Adobe Systems filed a letter with the SEC addressed directly to its shareholders, urging them to ignore the negative ISS recommendation on the company's executive pay packages. ${ }^{192}$ The letter asserted that (1) the peer group ISS used to determine reasonable pay for Adobe's executives was improper, (2) ISS overvalued the worth of the executives' stock options, (3) ISS failed to appropriately account for "fluctuations in market value" that impact "the real value of equity awards," and (4) the company has actually been quite responsive to shareholder concerns about executive pay. ${ }^{193}$

At Adobe's annual meeting on April 12, the say-on-pay proposal received about 224 million votes in favor, 163 million opposed, 3 million abstentions, and 47 million "Broker Non-Votes." 194 Counting only those votes indicating a for/against preference, the proposal passed with $57.9 \%$ of this vote. ${ }^{195}$ Including abstentions and non-preferences, the proposal garnered a more modest $51.3 \%$ of all shares at

189 Adobe Sys. Inc., Definitive Proxy Statement 34 (Form DEF 14A) (Mar. 1, 2012).

190 See id. at 33-34, 49, 63.

191 See Adobe Sys. Inc., Definitive Additional Materials 1 (Form DEF 14A) (Apr. 2, 2012).

192 Id.

193 Id. at 1-3.

194 Adobe Sys. Inc., Current Report 2 (Form 8-K) (Apr. 13, 2012).

195 See id. 
the meeting. ${ }^{196}$ The company thus came perilously close to failing its say-on-pay vote, suggesting that its strategy of contesting the validity of the ISS negative recommendation is a risky one. Time will tell if the company's strategy affects the 2013 shareholder say-on-pay vote.

\section{Case 4: Huntington Bancshares}

Huntington Bancshares Inc. is "a multi-state regional bank holding company" that, "[t]hrough the Bank, ... [its] only bank subsidiary," provides personal banking and specialty financial services for individuals and businesses through over 600 local branches across Ohio, Michigan, Indiana, Pennsylvania, West Virginia, and Kentucky. ${ }^{197}$ The bank received $\$ 1.4$ billion in TARP funds during the credit crisis, which it repaid shortly after going public in December $2010 .{ }^{198}$ Its stock is traded on the NASDAQ (HBAN), and in 2012 the company had a market capitalization of approximately $\$ 6$ billion. ${ }^{199}$

In its March 2012 proxy filing, Huntington began its CD\&A with the following prefatory note on its pay-for-performance philosophy: "Our compensation philosophy is to pay for performance that creates long-term shareholder value." 200 More specifically, the company's revised compensation program makes options and restricted stock the centerpieces of its long-term equity incentive program. ${ }^{201}$ The company explained the thinking behind its new pay structure as follows:

\section{Our 2011 Executive Compensation Program and Results}

During 2009 and through 2010, our executive compensation philosophy and pay components were limited as a result of our participation in TARP (i.e. cash performance incentives were prohibited and stock awards were limited to capped amounts of long-term restricted stock). In 2011, following repayment of our TARP capital in December 2010, we revised our compensation program to enhance our focus on performance-based incentives and on stock-based pay. We also implemented share ownership and hold until retirement

196 See id.

197 Huntington Bancshares Inc., Annual Report (Form 10-K) 1-2 (Feb. 17, 2012).

198 See Huntington's TARP Repayment Made, Columbus Bus. First (Dec. 22, 2010, 4:15 PM), http://www.bizjournals.com/columbus/news/2010/12/22/huntingtons-tarp-repaymentmade.html; Ohio Bank Sets $\$ 1.2$ Billion in Stock and Debt Offerings, N.Y. Times Dealbook (Dec. 13, 2010, 8:56 AM), http://dealbook.nytimes.com/2010/12/13/ohio-bank-sets-1-2-billion-instock-and-debt-offerings/.

199 HBAN Stock Price Today-Huntington Bancshares Inc. Stock Quote, WALL ST. J., http:/quotes.wsj.com/HBAN (last visited Sep. 15, 2012, 9:59 AM).

200 Huntington Bancshares Inc., Definitive Proxy Statement (Form 14A) 19 (Mar. 8, 2012).

201 See id. at 23. 
requirements that we believe are best in class and support our goal to align our executives with our shareholders. ${ }^{202}$

The proxy statement also pointed out that since hiring its new CEO, Stephen Steinour, in 2009, the bank's position has improved dramatically-specifically, net income had "improved significantly," the bank had "[r]eturned to profitab[ility]" in 2010 ("[one] year ahead of consensus analyst expectations"), its "Tier I common equity ratio ... ha[d] essentially doubled," and the bank's credit quality had improved. ${ }^{203}$ Compared to its peer group, Huntington's improvements in performance were significant. ${ }^{204}$ Consistent with its pay-forperformance policy, Huntington established a $41 \%$ cash to $59 \%$ longterm equity "targeted direct compensation mix" for Steinour and a $62 \%$ cash to $48 \%$ long-term equity "targeted direct compensation mix" for its other executive officers. ${ }^{205}$ The company's view on its new program is that "[s]tock options [a]re critical to fostering an alignment with shareholders." 206

Nevertheless, ISS issued a negative recommendation on the bank's long-term incentive plans because ISS's "five-year absolute test," which tracks CEO compensation and firm performance over a five year period, indicated the stock packages were excessive. ${ }^{207}$

On April 3, 2012, the company filed a letter to its shareholders, specifically refuting the ISS conclusions and urging shareholders to vote in favor of the proposal:

While we passed most of ISS' new 2012 tests, only the fiveyear absolute test showed a misalignment. This assessment and conclusion is inaccurate for two primary reasons:

i. The ISS five-year analysis period included two years attributed to our former CEO and did not consider only our performance and progress since Mr. Steinour joined in January 2009. Importantly, Huntington passed the ISS one- and three-year tests, periods aligned with performance under our current CEO.

ii. The ISS methodology for valuation of stock options incorporates a volatility assumption based on the last three-year period, a period of extreme bank stock price

202 Id. at 22.

203 Id. at 19-20.

$204 I d$. at 21.

205 See id. at 23, 26, 27.

206 Id. at 30.

207 See Huntington Bancshares, Inc., Definitive Additional Materials (Form 14A) 1 (Apr. 3, 2012). 
volatility due to the financial crises. As a result, ISS' volatility assumption is 3.6 times higher than the historically based long-term volatility assumption we used. ISS values our CEO's stock option grant at $\$ 5.4$ million over Huntington's \$2.97 million valuation, which was determined in accordance with generally accepted accounting principles in the United States (GAAP) and is consistent with SEC disclosure rules. ${ }^{208}$

The letter then raised specific objections to the ISS "against" recommendation: (1) the ISS valuation of Huntington's stock options was overstated, (2) the "ISS[ ] five year pay versus TSR analysis" underweighted the improvement in TSR and peer ranking achieved by the new CEO, and (3) the ISS was mistaken in "not view[ing] stock options as performance-based compensation." ${ }^{209}$ More broadly, the letter faulted the ISS for "not tak[ing] into account [the company's] compensation philosophy and program best practices." 210

Huntington's shareholders voted on the say-on-pay proposal as follows: $386,410,367$ votes in favor, 246,568,875 "Against/Withheld," $5,459,282$ abstentions, and 119,604,745 "Broker Non-Votes." 211 Thus, $61.0 \%$ of the votes (not counting abstention and broker non-votes) supported the pay packages, while a bare $51.0 \%$ of all shares at the meeting gave say-on-pay support. ${ }^{212}$ These voting results, quite similar to those at Adobe Systems, suggest grounds for concern for future say-on-pay votes at the company.

\section{Conclusions}

The first year of say-on-pay under Dodd-Frank confirmed that executive pay is on the minds of shareholders in U.S. companies. Led by the ISS, shareholders showed their concern-though not reflexively-about pay packages that rewarded CEOs despite weak company stock performance or that rewarded CEOs with excess pay compared to the pay of CEOs at similar companies. More than any factor, though, being targeted by the ISS for "outlier" pay practices was relevant to shareholder say-on-pay voting. In fact, our analysis suggests that negative ISS voting recommendations are more explanatory than any other factor identified in say-on-pay voting, thus merit-

\footnotetext{
208 Id.

209 Id. at $2-5$.

$210 \mathrm{Id}$. at 5.

211 Huntington Bancshares Inc., Current Report (Form 8-K) (Apr. 24, 2012).

212 See id.
} 
ing the immediate attention they typically have received from corporate management.

Changes in corporate governance behavior-such as more complete disclosure of pay-for-performance policies and the reversal of specific, controversial pay practices-inaugurated by say-on-pay in 2011 appear to be continuing apace and may be even gathering strength in 2012. Again led by ISS targeting of outlier companies, shareholders have shown that their scrutiny of pay practices in 2011 was not a passing phenomenon.

Mandatory say-on-pay, far from exposing lackadaisical interest by U.S. shareholders, offers a model of how procedural reformshere, an advisory vote by shareholders-can catalyze company-bycompany negotiations and reforms. This early experience with sayon-pay suggests that the regulation of specific pay practices, or the imposition of a binding vote by shareholders, would seem unnecessary given the responsiveness of corporate management to shareholder concerns about pay practices. The U.S. corporate governance system is proving itself adaptable and responsive to executive pay concernswith the right gentle nudge. 